\title{
Seasonal shifts in the contributions of the Changjiang River and the Kuroshio Current to nitrate dynamics in the continental shelf of the northern East China Sea based on a nitrate dual isotopic composition approach
}

\author{
Y. Umezawa ${ }^{1}$, A. Yamaguchi ${ }^{1}$, J. Ishizaka ${ }^{2}$, T. Hasegawa ${ }^{3}$, C. Yoshimizu ${ }^{4}$, I. Tayasu ${ }^{4}$, H. Yoshimura ${ }^{5}$, Y. Morii ${ }^{5}$, \\ T. Aoshima ${ }^{5}$, and N. Yamawaki ${ }^{5}$ \\ ${ }^{1}$ Graduate School of Fisheries Science and Environmental Studies, Nagasaki University, 1-14 Bunkyo-machi, Nagasaki city, \\ Nagasaki, 852-8521, Japan \\ ${ }^{2}$ Hydrospheric Atmospheric Research Center, Nagoya University, Furo-cho, Chikusa-ku, Nagoya, Aichi, 464-8601, Japan \\ ${ }^{3}$ Seikai National Fisheries Research Institute, Fisheries Research Agency, 1551-8 Taira-machi, Nagasaki 851-2213, Japan \\ ${ }^{4}$ Center for Ecological Research, Kyoto University, Japan, Hirano 2-509-3, Otsu city, Shiga, 520-2113, Japan \\ ${ }^{5}$ Faculty of Fisheries, Nagasaki University, 1-14 Bunkyo-machi, Nagasaki city, Nagasaki, 852-8521, Japan
}

Correspondence to: Y. Umezawa (umezawa@nagasaki-u.ac.jp)

Received: 31 March 2013 - Published in Biogeosciences Discuss.: 22 June 2013

Revised: 8 December 2013 - Accepted: 21 January 2014 - Published: 27 February 2014

\begin{abstract}
The northern East China Sea (ECS) serves as a spawning and nursery ground for many species of fish and squid. To clarify the basis of the food web in the northern ECS, we examined the nitrate $\left(\mathrm{NO}_{3}\right)$ dynamics along four latitudinal transects based on stable nitrogen and oxygen isotopes of $\mathrm{NO}_{3}\left(\delta^{15} \mathrm{~N}_{\mathrm{NO}_{3}}\right.$ and $\left.\delta^{18} \mathrm{O}_{\mathrm{NO}_{3}}\right)$ and temperaturesalinity dynamics in both winter (February 2009) and summer (July 2009 and July 2011). The $\delta^{15} \mathrm{~N}_{\mathrm{NO}_{3}}$ and $\delta^{18} \mathrm{O}_{\mathrm{NO}_{3}}$, which were distinctly different among the potential $\mathrm{NO}_{3}$ sources, were useful for clarifying $\mathrm{NO}_{3}$ sources and its actual usage by phytoplankton. In winter, Kuroshio Subsurface Water (KSSW) and the Yellow Sea Mixed Water (YSMW) predominantly contributed to $\mathrm{NO}_{3}$ distributed in the shelf water. In the surface water of the Okinawa Trough, $\mathrm{NO}_{3}$ from the $\mathrm{KSSW}$, along with a temperature increase caused by an intrusion of Kuroshio Surface Water (KSW), seemed to stimulate phytoplankton growth. In summer, Changjiang Diluted Water (CDW), Yellow Sea Cold Water Mass (YSCWM), and KSSW affected the distribution and abundance of $\mathrm{NO}_{3}$ in the northern ECS, depending on precipitation in the Changjiang drainage basin and the development of the YSCWM in the shelf bottom water. Although isotopic fractionation during $\mathrm{NO}_{3}$ uptake by phytoplankton seemed to drastically increase $\delta^{15} \mathrm{~N}_{\mathrm{NO}_{3}}$ and $\delta^{18} \mathrm{O}_{\mathrm{NO}_{3}}$ in summer, relatively light nitrate with
\end{abstract}

$\delta^{15} \mathrm{~N}_{\mathrm{NO}_{3}}$ lower than expected from this fractionation effect might be explained by contribution of atmospheric nitrogen and/or nitrification to $\mathrm{NO}_{3}$ dynamics in the surface and subsurface layers. If the latter were a dominant process, this would imply a tightly coupled nitrogen cycle in the shelf water of the northern ECS.

\section{Introduction}

Surrounded by China, Korea, Japan, and Taiwan, the East China Sea (ECS) is a very productive marginal sea that is used as a spawning and nursery ground by many species of fish and squid (Sakurai et al., 2000; Hiyama et al., 2002). For example, the jack mackerel, one of the most commercially important fish resources, hatches during winter in the southern ECS, and juveniles migrate in early summer to northern areas along the shelf-break region of the central ECS and then move farther north in late summer (Sassa et al., 2006, 2009). Therefore, primary production and subsequent zooplankton production in the ECS during each season, as well as the corresponding nutrient supplies supporting phytoplankton growth, need better understanding because of their importance as food sources for juvenile fishes. 
Changing nutrient conditions in the ECS, such as reduced silicate (Gong et al., 2006), limited phosphorus (Chai et al., 2009), and eutrophication ( $\mathrm{Li}$ and Daler, 2004), are important factors effecting the ecosystem, including primary production (Gong et al., 2006), blooms of the dinoflagellate Prorocentrum spp. (Dai et al., 2013; Kiyomoto et al., 2013), and the numbers of the giant jellyfish Nemopilema nomurai (Uye, 2008), which preys on fish eggs and larvae and competes with juvenile fishes for micro- and mesozooplankton.

Nitrate is the predominant DIN (dissolved inorganic nitrogen) species in the ECS, and new nitrogen is supplied by many rivers (Wong et al., 1998; Wang, 2006; Siswanto et al., 2008a; Liu et al., 2010b), intrusions from surrounding oceans (see below), bottom water (Hung and Gong, 2011; Shiozaki et al., 2011) and occasional deposition from the atmosphere (Nakamura et al., 2005, 2006; Kodama et al., 2011). The water on the continental shelf in the northern ECS is a mixture of Changjiang Diluted Water (CDW), Kuroshio Surface Water (KSW), Kuroshio Subsurface Water (KSSW), Yellow Sea Cold Water Mass (YSCWM), and Taiwan Warm Current Water (TWCW) (e.g., Ichikawa and Beardsley, 2002; Liu et al., 2010b). Shelf mixed water (SMW) forms from these with a mixing ratio that varies with location and season (e.g., Zhang et al., 2007a). In summer, the nutrient-rich Changjiang buoyant plume disperses eastward and reaches as far as the shelf break (Isobe et al., 2004), whereas in winter, when precipitation is limited and a northerly wind prevails, CDW flows southward along the coast (Chen, 2008; Han et al. 2013). In summer, Taiwan Strait Warm Water (TSWW) flows dominantly northeastward along with KSW, and these waters merge northeast of Taiwan due to impingement of the Kuroshio on the continental shelf and by onshore intrusion caused by frontal eddy motion around the shelf edge (Zhu et al., 2004; Guo et al., 2006; Lee and Matsuno, 2007). In northern areas of the ECS, the southern part of YSCWM develops in summer and decays in fall (Zhang et al., 2008). Then, in winter, the warm Kuroshio intrusion becomes gradually stronger relative to the YSCWM, and contacts nutrient-rich SMW, triggering diatom proliferation (Chiang et al., 2004). Hence, water characteristics and associated nutrient supplies in the ECS are very complex and show significant seasonal variation. Some nutrient budgets for shelf areas of the ECS have so far been evaluated by box models based on the nutrient concentrations of each water mass and the concept of conservation of water and salt masses (Chen and Wang, 1999; Zhang et al., 2007a) or in combination with Ra (radium) isotopes (Zhang et al., 2007b). However, nutrient budget models do not indicate a contribution of each water-massderived nutrient to primary production on the shelf. Moreover, the possibility of a higher contribution of nitrification to $\mathrm{NO}_{3}$ dynamics in the euphotic zone (Shiozaki et al., 2011) and a lower $f$ ratio on the shelf (Chen et al., 2001, Chen and Chen, 2003) make it difficult to assess the contribution of each new source of nitrogen to primary production. Spa- tial and temporal variation in these nutrient supplies and their availability to phytoplankton remain uncertain.

Stable isotopes of $\mathrm{NO}_{3}$ have been effectively applied to clarify $\mathrm{NO}_{3}$ dynamics in several coastal areas and in oceanic waters. Both of the heavier isotopes of $\mathrm{NO}_{3}$ (i.e., ${ }^{15} \mathrm{~N}$ and ${ }^{18} \mathrm{O}$ ) react more slowly in enzyme-mediated reactions, such as $\mathrm{NO}_{3}$ assimilation and denitrification, resulting in a gradual increase in heavier isotopes of the remaining $\mathrm{NO}_{3}$ at a specific ratio (e.g., ${ }^{18} \varepsilon:{ }^{15} \varepsilon=1$ for assimilation by eukaryotic phytoplankton and cyanobacteria; ${ }^{18} \varepsilon:{ }^{15} \varepsilon=2$ for heterotrophic bacteria [Granger et al., 2004, 2010]; and ${ }^{18} \varepsilon:{ }^{15}$ $\varepsilon=0.5$ to 1.0 for denitrification [Chen and MacQuarrie, 2005; Granger et al., 2008], where ${ }^{18} \varepsilon$ and ${ }^{15} \varepsilon$ [\%o] are kinetic isotope effects expressed as the ratio of the reaction rates $[k]$ for the heavy and light isotopes as follows: ${ }^{18} \varepsilon$ $\left.\left[{ }^{15} \varepsilon\right]=\left({ }^{16} k /{ }^{18} k\left[{ }^{14} k /{ }^{15} k\right]-1\right) \times 1000\right)$ and various values in each $\mathrm{N}$ pool of the natural environment. Therefore, when the values of stable isotopes of each $\mathrm{NO}_{3}$ source are distinct from those of other sources, the information can be used to trace the contribution of each $\mathrm{NO}_{3}$ source (Leichter et al., 2007). Also, when $\mathrm{NO}_{3}$ is taken up by phytoplankton and bacteria following a Rayleigh fractionation model in a closed system, a linear relationship is observed between the log-transformed $\mathrm{NO}_{3}$ concentration $\left(\ln \left[\mathrm{NO}_{3}\right]\right)$ and $\delta^{15} \mathrm{~N}$ in $\mathrm{NO}_{3}$ (Sigman et al., 1999; Teranes and Bernasconi, 2000). This provides evidence of actual uptake of $\mathrm{NO}_{3}$ by phytoplankton and other species (e.g., denitrifying bacteria), and the extent of any deviation from linearity suggests the presence of other biological reactions in the $\mathrm{N}$ cycle, such as nitrogen fixation (Sigman et al., 2005) and nitrification (Wankel et al., 2007; Sugimoto et al., 2009). Because isotopic signatures provide time- and space-integrated evidence of multiple biogeochemical processes (Wankel et al., 2007), this information should be helpful for better understanding of $\mathrm{NO}_{3}$ dynamics on the shelf of the ECS, which have previously been explored from only snapshot surveys and water mass analysis.

Therefore, in this study, we investigated the primary mechanisms that control $\delta^{15} \mathrm{~N}$ and $\delta^{18} \mathrm{O}$ values in $\mathrm{NO}_{3}$ in northern ECS areas. The investigation explored the sources of $\mathrm{NO}_{3}$ supplied to northern ECS areas and the actual use of $\mathrm{NO}_{3}$ by phytoplankton in winter and summer, based on information from multiple isotopes of $\mathrm{NO}_{3}$ combined with other traditional conservative parameters (salinity and temperature).

\section{Materials and methods}

\subsection{Study site}

The ECS is a marginal sea surrounded by the Eurasian continent and a chain of islands, and is connected to the Yellow Sea in the north and the South China Sea through the Taiwan Strait in the south (Fig. 1). More than $70 \%$ of the area of the ECS is shallow $(<200 \mathrm{~m})$ continental shelf, but the deep Okinawa Trough (ca. 1000 to $2000 \mathrm{~m}$ ) is located in 


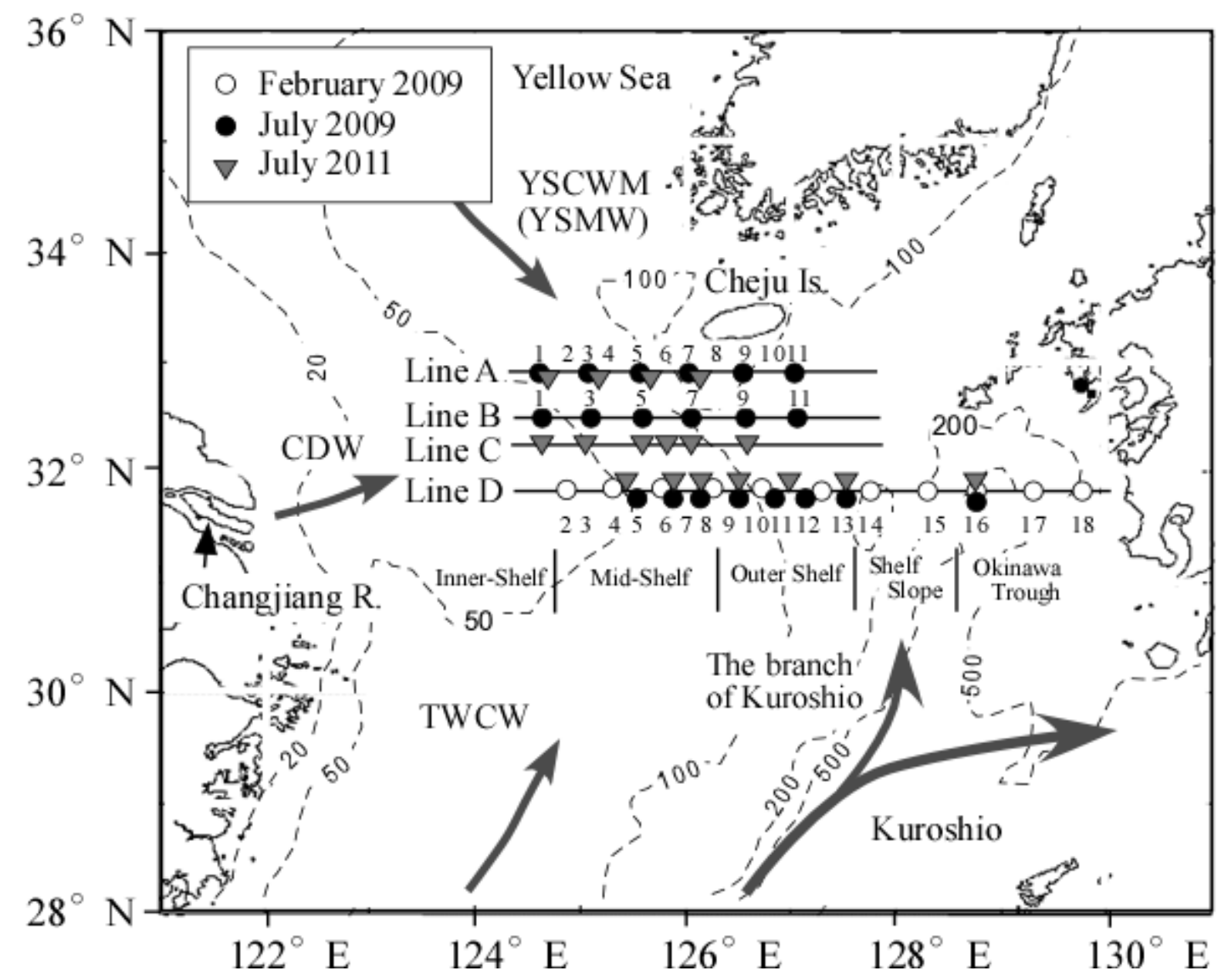

Fig. 1. Map of East China Sea showing the sampling stations in February and July 2009 and July 2011. A schematic image of the Kuroshio Current, Taiwan Warm Current Water (TWCW), Yellow Sea Cold Water Mass (YSCWM) and Changjiang Diluted Water (CDW) during summer and Yellow Sea Mixed Water (YSMW) during winter is also shown. The dashed lines indicate the isobath.

the southeastern and eastern ECS. A strong western boundary current, much like the Gulf Stream, the Kuroshio originates from bifurcation of the North Equatorial Current east of Mindanao Island of the Philippines in the North Pacific Ocean, and a main branch of the Kuroshio flows northward through the Okinawa Trough. The climate in the ECS during summer (May to October) is roughly categorized as the rainy season, due to monsoonal southerly oceanic winds and tropical typhoons, whereas during winter (November to April) it is classified as the dry season largely due to the northerly monsoon originating from the Asian continent. Accordingly, seasonal changes in the discharge of the Changiiang River, which is one of the five largest rivers in the world by discharge volume, and the development of the YSCWM and TWCW highly affect the hydrographic characteristics and potentially the nutrient dynamics of the ECS.

Field observations and water sampling for chemical analyses were carried out in the northern ECS on three cruises:
4-10 February 2009 aboard the RV Yoko-Maru (Fisheries Research Agency) and 17-27 July 2009 and 15-25 July 2011 aboard the training vessel (TV) Nagasaki-Maru (Nagasaki University). One main latitudinal transect (Line D: $31^{\circ} 45.00^{\prime} \mathrm{N}$ ), from the deep Okinawa Trough to the midshelf area, had been intensively surveyed throughout the three cruises. During the two summer cruises, surveys were also conducted along three other transects (Line A: $32^{\circ} 55.00^{\prime}$ $\mathrm{N}$; Line B: $32^{\circ} 30.00^{\prime} \mathrm{N}$; and Line C: $32^{\circ} 15.00^{\prime} \mathrm{N}$ ), along which the runoff from the Changjiang River is commonly distributed during summer.

\subsection{Field observations}

Hydrographic conditions were measured along the transects by profiling from the surface to within $5 \mathrm{~m}$ of the bottom using a conductivity-temperature-depth (CTD) recorder (SBE 9plus; Seabird Electronics, Inc.) attached with a 
chlorophyll fluorometer (Seapoint chlorophyll fluorometer, Seapoint Sensors, Inc.) and a dissolved oxygen sensor (SBE43; Seabird Electronics, Inc.). CTD casts were made at intervals of about $23.7 \mathrm{~km}$ in February 2009 and at intervals of about $31.2 \mathrm{~km}$ in July 2009 and July 2011.

Water samples were collected from different layers (i.e., surface, $10 \mathrm{~m}, 20 \mathrm{~m}, 30 \mathrm{~m}, 50 \mathrm{~m}, 75 \mathrm{~m}, 125 \mathrm{~m}, 200 \mathrm{~m}, 400 \mathrm{~m}$, $600 \mathrm{~m}$, and chlorophyll maximum, $5 \mathrm{~m}$ from the bottom, varying with the water depth) using 12 Niskin bottles $(5 \mathrm{~L})$ mounted on a Rosette sampler (General Oceanics, Inc.) with a CTD probe (SBE 9/11; Seabird Electronics, Inc.) and then were filtered through $0.2 \mu \mathrm{m}$ cellulose acetate filters. Aliquots for analysis of nutrients and stable isotopes of $\mathrm{NO}_{3}$ were put immediately into acrylic tubes and polyethylene bottles, which were rinsed with distilled water followed by two rinses with sample water. All samples were kept frozen at $-20^{\circ} \mathrm{C}$ until analysis.

\subsection{Nutrient and stable isotope analyses}

The concentrations of nitrate $\left(\left[\mathrm{NO}_{3}\right]\right)$, nitrite $\left(\left[\mathrm{NO}_{2}\right]\right)$ and other nutrients $\left(\left[\mathrm{NH}_{4}\right],\left[\mathrm{PO}_{4}\right]\right)$ in the water samples were measured colorimetrically using an autoanalyzer (AACS 4; BLTEC, Japan). For water samples with more than about $1.5 \mu \mathrm{M}-\mathrm{NO}_{3}$, the stable nitrogen and oxygen isotope ratios (i.e., $\delta^{15} \mathrm{~N}$ and $\delta^{18} \mathrm{O}$ ) in $\mathrm{NO}_{3}+\mathrm{NO}_{2}$ were determined using the denitrifier methods of Sigman et al. (2001) and Casciotti et al. (2002). Although the samples included a small amount of $\mathrm{NO}_{2}$ (i.e., less than 3 and $15 \%$ of nitrate in summer and winter, respectively), $\mathrm{NO}_{2}$ was not removed, so $\mathrm{NO}_{3}+\mathrm{NO}_{2}$ is hereafter described simply as nitrate $\left(\mathrm{NO}_{3}\right)$ unless specified otherwise.

In brief, $\mathrm{NO}_{3}$ was converted into nitrous oxide $\left(\mathrm{N}_{2} \mathrm{O}\right)$ by denitrifying bacteria that lack $\mathrm{N}_{2} \mathrm{O}$-reductase activity. The $\mathrm{N}_{2} \mathrm{O}$ was stripped from the sample vial using $\mathrm{He}$ as the carrier gas, purified using cryogenic trapping (Precon System; Finnigan MAT, Bremen, Germany), separated chromatographically (Finnigan GasBench), and analyzed using mass spectrometry (Finnigan Delta ${ }^{\text {plus }} \mathrm{XP}$ ). The ratios of ${ }^{15} \mathrm{~N}:{ }^{14} \mathrm{~N}$ and ${ }^{18} \mathrm{O}:{ }^{16} \mathrm{O}$ were expressed relative to atmospheric nitrogen and Vienna standard mean ocean water (V-SMOW), respectively, and were calculated as follows:

$$
\delta^{15} \mathrm{~N}, \delta^{18} \mathrm{O}=\{[R(\text { sample }) / R(\text { standard })]-1\} \times 1000(\%),
$$

where $R={ }^{15} \mathrm{~N} /{ }^{14} \mathrm{~N}$ or ${ }^{18} \mathrm{O} /{ }^{16} \mathrm{O}$. The isotope values were calibrated using the laboratory working standard and the internationally recognized nitrate standards IAEA-N3 and USGS34. Based on replicate measurements of standards and samples, analytical precision for $\delta^{15} \mathrm{~N}$ and $\delta^{18} \mathrm{O}$ was generally better than $\pm 0.2 \%$ and $\pm 0.3 \%$, respectively.

\section{Results}

\subsection{Hydrographic characteristics}

The vertical distributions of physical and chemical parameters along the observational transects (Figs. 2 and 3) clearly showed seasonal and year-to-year differences in water dynamics on the shelf of the northern ECS.

In winter, when the strong northwest monsoon prevailed and surface water was cooled, water on the shelf was completely mixed from surface to bottom with an increasing offshore gradient of salinity and temperature (Fig. 2a, d). Water density was nearly constant throughout the study area, except for the shelf-break region (Sta. D12-16) due to the presence of a warmer (i.e., $18-20^{\circ} \mathrm{C}$, Fig. 2d) and more saline (i.e., more than 34.5, Fig. 2a) water mass at the surface. Although the $\mathrm{NO}_{3}$ concentration in this warm surface water was relatively low (i.e., 1.6 to $1.7 \mu \mathrm{M}$ ), nutrient content remained above $1.0 \mu \mathrm{M}$ even in the surface water throughout the transect (Fig. 2p). Higher chlorophyll fluorescence was observed in surface water at the Okinawa Trough (Sta. D16-18, Fig. 2m), where the water was relatively warm (i.e., $17-18^{\circ} \mathrm{C}$ ) and had 3.0 to $4.0 \mu \mathrm{M} \mathrm{NO}_{3}$ (Fig. 2p). However, chlorophyll fluorescence was lower in surface water of the mid-shelf, where the water was relatively cold (i.e., 10$12^{\circ} \mathrm{C}$ ), despite higher $\mathrm{NO}_{3}$ concentrations of 9.0 to $11.0 \mu \mathrm{M}$.

In summer 2009 and 2011, strong stratification due to heating and freshwater from the Changiiang River was observed in the surface water (Fig. 2h, i). In 2011, along the southern transect, Line $\mathrm{D}$, a lower-salinity water mass existed in the surface layer (Sta. D6', Fig. 2c), while a cold water mass (Sta. D6'-9', Fig. 2f) was observed at the bottom layer. Some patches with a few micromoles $\mathrm{NO}_{3}$ (Sta. D11, salinity of 30.3) were distributed in the surface water in 2011 (Fig. 2r), but not in 2009, while most of the surface water from the mid-shelf to shelf-slope zone was completely depleted in nutrients in summer. Nitrate concentration increased by up to $12 \mu \mathrm{M}$ from the subsurface water to the bottom water. The layer of maximum chlorophyll was at a depth of about 10 $\mathrm{m}$ at the mid-shelf area (Sta. D2-5) but gradually decreased to the subsurface layer at a depth of 30 to $40 \mathrm{~m}$ towards the shelf edge and then deeper than $50 \mathrm{~m}$ in the shelf-slope area (Sta. D16) (Fig. 2n, o). Higher oxygen concentration (mg $\mathrm{L}^{-1}$ ) corresponded to the subsurface-layer chlorophyll maximum, reflecting active primary production, while a lower oxygen concentration of less than $4.0 \mathrm{mg} \mathrm{L}^{-1}$ was observed near the bottom layer on the shelf in summer (Fig. 2k,1). In the northern shelf area (i.e., lines A, B, and C), where the Changjiang River plume spreads out in summer (Isobe and Matsuno, 2008), lower salinity in the surface layer was distributed over a larger area (Fig. 3a-d) compared to the southern area (i.e., Line D, Fig. 2a-c). Therefore, $\mathrm{NO}_{3}$ remained, even at shallower depths, at many locations in summer (Fig. 3u-x), and higher chlorophyll concentration was 

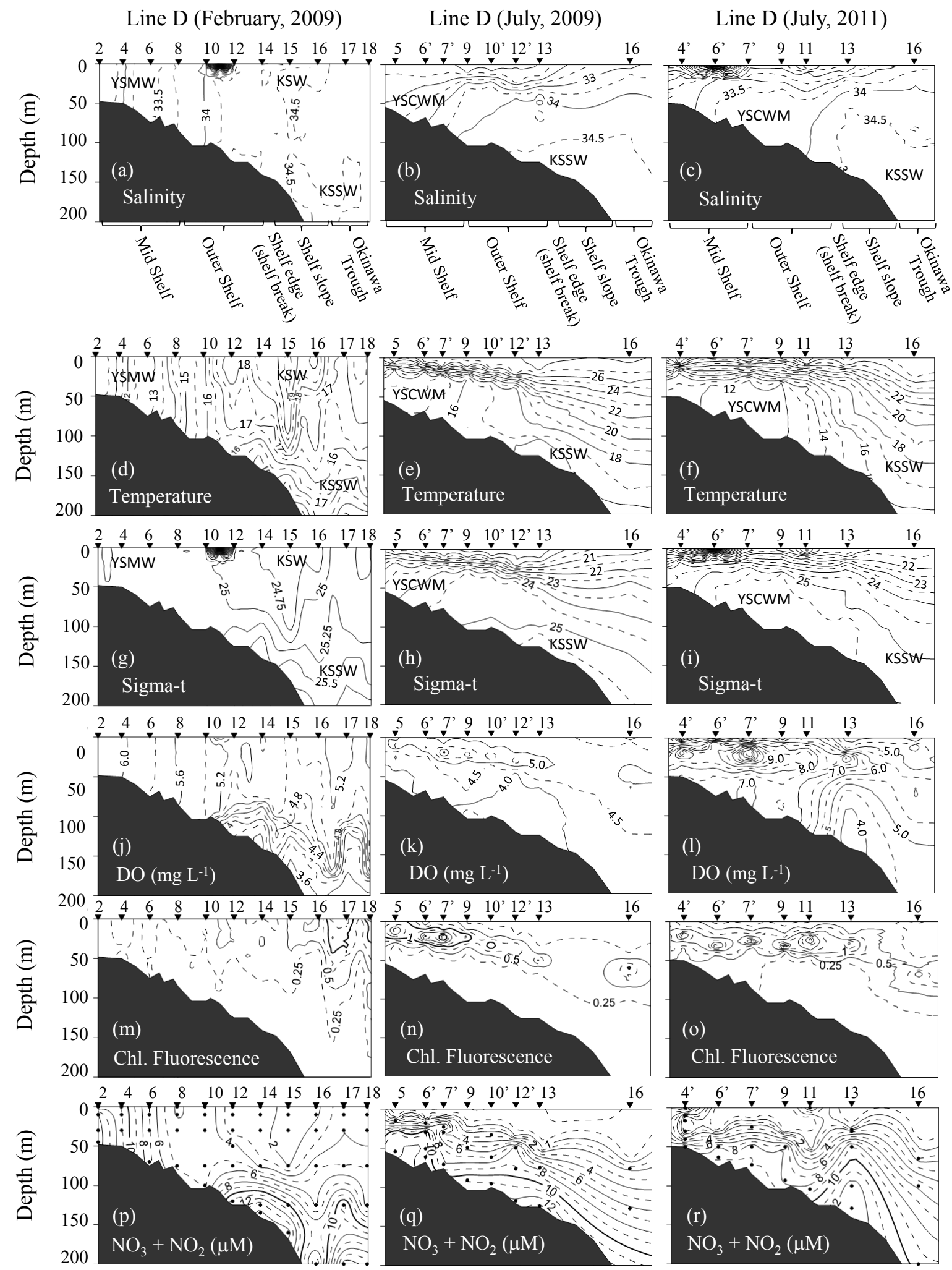

Fig. 2. Vertical distribution of physical parameters, chlorophyll fluorescence, and nitrate concentrations along Line D in February and July 2009 and July 2011. The black circles in the $\mathrm{NO}_{3}+\mathrm{NO}_{2}$ figure indicate the location where $\mathrm{NO}_{3}$ concentration was more than $1.5 \mu \mathrm{M}$, and $\delta^{15} \mathrm{~N}$ and $\delta^{18} \mathrm{O}$ in $\mathrm{NO}_{3}$ were analyzed. 
Line A (July, 2009)

Line B (July, 2009)

Line A (July, 2011)

Line C (July, 2011)
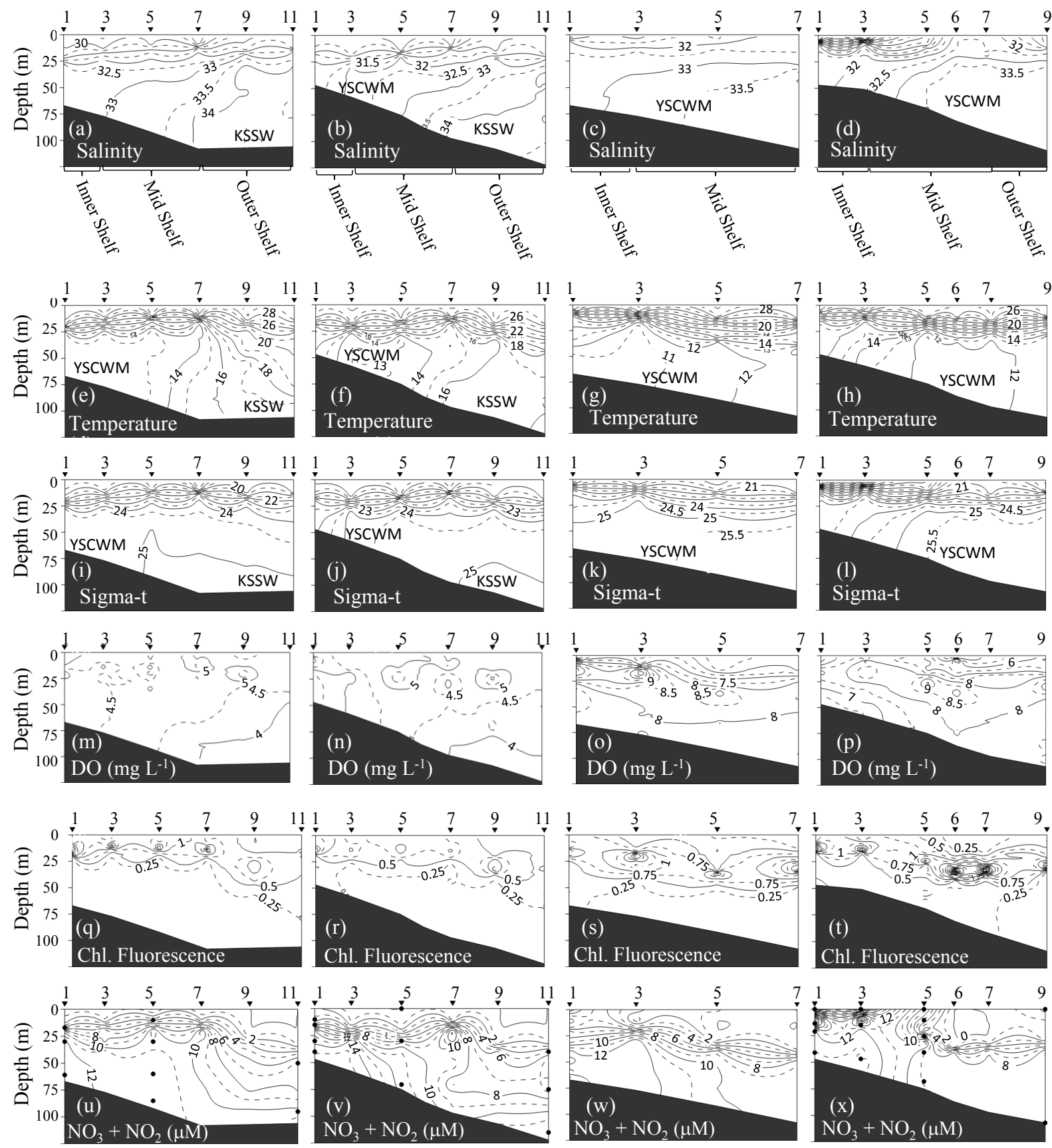

Fig. 3. Vertical distribution of physical parameters, chlorophyll fluorescence, and nitrate concentrations along lines A and B in July 2009 and lines $\mathrm{A}$ and $\mathrm{C}$ in July 2011. The black circles in the $\mathrm{NO}_{3}+\mathrm{NO}_{2}$ figure are the same as in Fig. 2.

correspondingly observed in shallow depth in the northern area (Fig. 3q-t).

\subsection{Spatial distribution and characteristics of nitrate}

There were lateral and vertical variations in both the nitrogen and oxygen stable isotope signatures of $\mathrm{NO}_{3}\left(\delta^{15} \mathrm{~N}_{\mathrm{NO}_{3}}\right.$ and $\delta^{18} \mathrm{O}_{\mathrm{NO}_{3}}$ ) along the southern line, Line $\mathrm{D}$ (Fig. 4, Tables 1-3). Relatively lower $\delta^{15} \mathrm{~N}$ and $\delta^{18} \mathrm{O}$ values (i.e., $\delta^{15} \mathrm{~N}<6.0 \%$ o, $\delta^{18} \mathrm{O}<4.0 \%$ o) were observed in the deep layer at the Okinawa Trough (Sta. D16-18) and in the bottom water of the shelf-slope area (Sta. D14-15), irrespective of season. Similar $\delta^{15} \mathrm{~N}_{\mathrm{NO}_{3}}$ and $\delta^{18} \mathrm{O}_{\mathrm{NO}_{3}}$ values were observed 
Table 1. Nitrate concentration and $\delta^{15} \mathrm{~N}$ and $\delta^{18} \mathrm{O}$ in nitrate at each layer of the sampling stations in February 2009. The depth (m) in parentheses indicates the water depth, and the layers with asterisks are the chlorophyll maximum.

\begin{tabular}{|c|c|c|c|c|c|c|c|c|c|c|c|}
\hline Station & Latitude & Longitude & Layer & {$\left[\mathrm{NO}_{3}^{-}+\mathrm{NO}_{2}^{-}\right]$} & {$\left[\mathrm{NH}_{4}^{+}\right]$} & {$\left[\mathrm{PO}_{4}^{3-}\right]$} & $\mathrm{N}^{*}$ & $\delta^{15} \mathrm{~N}$ & $\delta^{18} \mathrm{O}$ & Salinity & Date \\
\hline \multirow[t]{4}{*}{ D-2 } & 31.80 & 124.83 & 0 & 11.1 & 0.2 & 0.8 & 1.4 & 6.7 & 7.0 & 32.63 & Feb 09 \\
\hline & & & 10 & 14.1 & 0.6 & 0.7 & 6.4 & 6.7 & 8.0 & 32.63 & \\
\hline & & & 30 & 14.4 & 0.2 & 0.8 & 4.7 & 6.6 & 6.9 & 32.67 & \\
\hline & & & $45(48)$ & 14.5 & 0.7 & 0.7 & 6.9 & 6.8 & 7.4 & 32.68 & \\
\hline \multirow[t]{3}{*}{ D-4 } & 31.80 & 125.25 & 0 & 10.9 & 1.5 & 0.7 & 4.1 & 7.2 & 8.1 & 32.92 & Feb 09 \\
\hline & & & 10 & 11.1 & 2.0 & 0.6 & 6.4 & 7.0 & 8.6 & 32.92 & \\
\hline & & & $30(50)$ & 11.1 & 1.8 & 0.7 & 4.6 & 7.2 & 7.7 & 32.96 & \\
\hline \multirow[t]{4}{*}{ D-6 } & 31.80 & 125.75 & 0 & 7.0 & 5.3 & 0.5 & 7.2 & 7.1 & 8.4 & 33.38 & Feb 09 \\
\hline & & & 10 & 7.0 & 1.3 & 0.5 & 3.2 & 6.9 & 8.5 & 33.38 & \\
\hline & & & 30 & 7.1 & 1.8 & 0.5 & 3.8 & 7.0 & 7.6 & 33.38 & \\
\hline & & & $60(75)$ & 7.3 & 4.2 & 0.5 & 6.4 & 6.7 & 7.7 & 33.38 & \\
\hline \multirow[t]{4}{*}{ D-8 } & 31.80 & 126.25 & 0 & 3.8 & 3.2 & 0.3 & 5.1 & 7.3 & 11.2 & 33.83 & Feb 09 \\
\hline & & & 10 & 3.9 & 2.1 & 0.3 & 4.1 & 7.1 & 13.4 & 33.83 & \\
\hline & & & 30 & 4.3 & 0.7 & 0.3 & 3.1 & 6.7 & 10.0 & 33.79 & \\
\hline & & & $75(85)$ & 4.8 & 1.2 & 0.4 & 2.5 & 6.7 & 9.4 & 33.76 & \\
\hline \multirow[t]{5}{*}{ D-10 } & 31.80 & 126.75 & 0 & 5.0 & 1.0 & 0.4 & 2.5 & 6.5 & 8.6 & 34.02 & Feb 09 \\
\hline & & & 10 & 5.0 & 0.9 & 0.4 & 2.4 & 6.6 & 9.6 & 34.02 & \\
\hline & & & 30 & 4.8 & 0.4 & 0.4 & 1.7 & 6.5 & 9.3 & 34.02 & \\
\hline & & & 75 & 4.8 & 1.4 & 0.4 & 2.7 & 6.4 & 9.0 & 34.01 & \\
\hline & & & $100(104)$ & 4.8 & 1.4 & 0.4 & 2.7 & 6.3 & 9.4 & 34.01 & \\
\hline \multirow[t]{6}{*}{ D-12 } & 31.80 & 127.25 & 0 & 2.4 & 2.7 & 0.2 & 4.8 & 8.0 & 10.7 & 34.48 & Feb 09 \\
\hline & & & $10^{*}$ & 2.3 & 1.2 & 0.2 & 3.2 & 8.1 & 9.0 & 34.48 & \\
\hline & & & $30^{*}$ & 2.3 & 2.8 & 0.2 & 4.8 & 8.3 & 8.6 & 34.46 & \\
\hline & & & 50 & 4.6 & 1.9 & 0.4 & 3.0 & 5.7 & 5.8 & 34.42 & \\
\hline & & & 75 & 5.2 & 2.0 & 0.4 & 3.7 & 5.6 & 5.9 & 34.45 & \\
\hline & & & $121(125)$ & 11.4 & 0.3 & 0.8 & 1.8 & 5.5 & 4.2 & 34.51 & \\
\hline \multirow[t]{6}{*}{ D-14 } & 31.80 & 127.75 & 0 & 2.9 & 2.2 & 0.2 & 4.8 & 7.2 & 10.9 & 34.50 & Feb 09 \\
\hline & & & 10 & 2.8 & 1.2 & 0.2 & 3.7 & 7.4 & 9.3 & 34.50 & \\
\hline & & & $30^{*}$ & 2.4 & 1.6 & 0.2 & 3.7 & 7.6 & 11.9 & 34.50 & \\
\hline & & & 75 & 3.6 & 1.0 & 0.3 & 2.7 & 6.4 & 7.8 & 34.47 & \\
\hline & & & 125 & 13.8 & 1.3 & 1.0 & 2.0 & 5.8 & 3.9 & 34.50 & \\
\hline & & & $139(141)$ & 14.1 & 2.3 & 0.9 & 4.9 & 5.6 & 3.6 & 34.49 & \\
\hline \multirow[t]{6}{*}{ D-15 } & 31.80 & 128.25 & $0^{*}$ & 1.6 & 2.3 & 0.2 & 3.6 & 7.2 & 9.6 & 34.55 & Feb 09 \\
\hline & & & $10^{*}$ & 1.6 & 0.8 & 0.2 & 2.1 & 7.3 & 8.5 & 34.55 & \\
\hline & & & $30^{*}$ & 1.5 & 2.3 & 0.1 & 5.1 & 7.4 & 9.4 & 34.55 & \\
\hline & & & 75 & 1.9 & 0.2 & 0.2 & 1.8 & 6.5 & 7.9 & 34.54 & \\
\hline & & & 125 & 10.2 & 1.9 & 0.7 & 3.8 & 5.7 & 4.0 & 34.52 & \\
\hline & & & $165(168)$ & 14.6 & 1.3 & 1.0 & 2.8 & 5.8 & 4.0 & 34.50 & \\
\hline \multirow[t]{8}{*}{ D-16 } & 31.80 & 128.75 & 0 & 1.7 & 1.7 & 0.2 & 3.1 & 8.5 & 11.4 & 34.54 & Feb 09 \\
\hline & & & 10 & 1.8 & 1.2 & 0.2 & 2.7 & 8.8 & 11.1 & 34.54 & \\
\hline & & & $30^{*}$ & 2.4 & 2.4 & 0.2 & 4.5 & 7.5 & 8.4 & 34.52 & \\
\hline & & & 75 & 4.8 & 1.5 & 0.4 & 2.8 & 5.8 & 6.1 & 34.48 & \\
\hline & & & 125 & 5.8 & 2.4 & 0.4 & 4.7 & 5.5 & 6.5 & 34.47 & \\
\hline & & & 200 & 6.0 & 2.5 & 0.4 & 5.0 & 6.0 & 6.9 & 34.51 & \\
\hline & & & 300 & 19.5 & 1.5 & 1.2 & 4.7 & 6.1 & 3.4 & 34.43 & \\
\hline & & & $500(762)$ & 30.6 & 0.7 & 2.1 & 0.6 & 6.4 & 3.0 & 34.36 & \\
\hline
\end{tabular}


Table 1. Continued.

\begin{tabular}{|c|c|c|c|c|c|c|c|c|c|c|c|}
\hline Station & Latitude & Longitude & Layer & {$\left[\mathrm{NO}_{3}^{-}+\mathrm{NO}_{2}^{-}\right]$} & {$\left[\mathrm{NH}_{4}^{+}\right]$} & {$\left[\mathrm{PO}_{4}^{3-}\right]$} & $\mathrm{N}^{*}$ & $\delta^{15} \mathrm{~N}$ & $\delta^{18} \mathrm{O}$ & Salinity & Date \\
\hline \multirow[t]{8}{*}{ D-17 } & 31.80 & 129.25 & $0^{*}$ & 3.9 & 0.7 & 0.3 & 2.7 & 7.8 & 9.1 & 34.48 & Feb 09 \\
\hline & & & $10^{*}$ & 3.5 & 0.1 & 0.3 & 1.7 & 7.8 & 8.7 & 34.48 & \\
\hline & & & 30 & 4.0 & 1.3 & 0.3 & 3.4 & 7.7 & 8.7 & 34.47 & \\
\hline & & & 75 & 5.0 & 2.8 & 0.4 & 4.3 & 6.7 & 7.5 & 34.47 & \\
\hline & & & 125 & 11.4 & 1.5 & 0.7 & 4.6 & 5.8 & 3.9 & 34.51 & \\
\hline & & & 200 & 16.7 & 2.0 & 1.1 & 4.0 & 5.9 & 3.5 & 34.48 & \\
\hline & & & 300 & 24.0 & 3.8 & 1.5 & 6.7 & 6.1 & 3.6 & 34.38 & \\
\hline & & & $500(757)$ & 33.4 & 1.1 & 2.0 & 5.4 & 6.1 & 3.4 & 34.37 & \\
\hline \multirow[t]{7}{*}{ D-18 } & 31.80 & 129.67 & 0 & 3.4 & 2.3 & 0.3 & 3.8 & 7.1 & 10.8 & 34.48 & Feb 09 \\
\hline & & & $10^{*}$ & 3.1 & 0.4 & 0.2 & 3.2 & 7.5 & 9.7 & 34.48 & \\
\hline & & & 30 & 3.3 & 0.6 & 0.3 & 2.0 & 7.1 & 9.6 & 34.48 & \\
\hline & & & 75 & 4.9 & 0.8 & 0.4 & 2.2 & 6.0 & 8.0 & 34.48 & \\
\hline & & & 125 & 5.4 & 1.0 & 0.4 & 2.9 & 6.5 & 6.5 & 34.43 & \\
\hline & & & 200 & 15.6 & 0.8 & 1.1 & 1.7 & 6.0 & 3.9 & 34.48 & \\
\hline & & & $300(450)$ & 22.8 & 0.3 & 1.5 & 2.0 & 5.9 & 3.5 & 34.38 & \\
\hline
\end{tabular}

in the bottom water from the outer shelf to near the mid-shelf (Sta. D9, 10', 12', and 13, Fig. 4b) in July 2009, although the extent of similar values was limited to the bottom water of the shelf-slope zone (Sta. D13, Fig. 4c) in July 2011. Similarly, a slight increase in $\delta^{15} \mathrm{~N}_{\mathrm{NO}_{3}}$ and $\delta^{18} \mathrm{O}_{\mathrm{NO}_{3}}$ in the bottom water was observed in different zones of the continental shelf in different years (i.e., [Sta. D5, 6'] in 2009 (Fig. 4b) and [D4'11] in 2011 (Fig. 4c)). $\delta^{15} \mathrm{~N}_{\mathrm{NO}_{3}}$ and $\delta^{18} \mathrm{O}_{\mathrm{NO}_{3}}$ values gradually increased in subsurface and surface water, reaching 8.3 and $13.4 \%$, respectively, in winter (Fig. 4a) and up to 21.7 and $25.9 \%$, respectively, in summer (Fig. $4 \mathrm{~b}$ and c). The ratio between $\delta^{18} \mathrm{O}$ and $\delta^{15} \mathrm{~N}$ increases $\left(\Delta \delta^{18} \mathrm{O} / \Delta \delta^{15} \mathrm{~N}\right)$ from several potential $\mathrm{NO}_{3}$ sources, such as bottom water on the shelf and Changjiang River water, seemed to be almost constant around 1 in summer, while within the range of 1 to 3 in winter. In winter, heavier values were observed extensively in the surface water from the Okinawa Trough to the outer shelf zone, but heavier values were observed in the subsurface layer from the outer shelf to the mid-shelf in summer. Values in July 2011 were heavier than those in July 2009. Irrespective of season and year, these heavier values seem to have occurred in layers where a chlorophyll maximum was observed (Fig. 4, Tables 1-3).

These characteristics of $\delta^{15} \mathrm{~N}_{\mathrm{NO}_{3}}$ and $\delta^{18} \mathrm{O}_{\mathrm{NO}_{3}}$ along the southern line, Line D, were also observed in the northern mid-shelf and outer shelf areas (i.e., lines A, B, and C; Fig. 5, Tables 1-3).

\section{Discussion}

\subsection{Hydrographic characteristics and nitrate dynamics on the continental shelf}

A matrix of temperature-salinity data (hereafter, $T-S$ diagram) was established for the water monitored during each survey (Fig. 6) to check seasonal and year-to-year differences in the contributions of water masses and associated new- $\mathrm{NO}_{3}$ inputs from adjacent areas to the SMW.

In winter, the formation of SMW was simple (Fig. 6a). Intrusion of warm $\mathrm{KSW}$ with low $\mathrm{NO}_{3}$ concentration was observed at the surface around the shelf-slope area. Zhang et al. (2007a) estimated that the water mass and associated $\mathrm{NO}_{3}$ supplied to the broad shelf region during winter was dominated by high-salinity water from the TWCW, which is formed mainly by intrusion from the Kuroshio around the region to the east of Taiwan. This occurs because the northerly monsoon prevails over the ECS, and Changjiang effluents are restricted to the western side of the ECS and disperse southward along the China coast (Chen, 2008). At the northern ECS, however, the $T-S$ diagram and vertical profiles along the southern line, Line D, suggested that the water mass and $\mathrm{NO}_{3}$ in the inner mid-shelf area were supplied by the $\mathrm{NO}_{3}$-rich Yellow Sea Mixed Water (YSMW), which came from the north (oval no. 1, Fig. 6a). The water in the mid-shelf and outer shelf zones appeared to be composed of a mix of YSMW and $\mathrm{NO}_{3}$-depleted KSW (diluted KSSW), which entered the ECS northeast of Taiwan and flowed along the shelf-slope (oval no. 2, Fig. 6a). Moreover, in the bottom layer at the outer shelf (Sta. D14, 15), $\mathrm{NO}_{3}$-rich KSSW, which flows along the shelf-slope, seemed to mix with shelf water, probably because of frontal eddy motion (oval no. 3, Fig. 6a) (e.g., Yanagi et al., 1998). Therefore, the $\mathrm{NO}_{3}$-rich YSMW and KSSW could be major sources of new $\mathrm{NO}_{3}$ to 
Table 2. Nitrate concentration and $\delta^{15} \mathrm{~N}$ and $\delta^{18} \mathrm{O}$ in nitrate at each layer of the sampling stations in July, 2009. The depth (m) in parentheses indicates the water depth, and the layers with asterisks are the chlorophyll maximum.

\begin{tabular}{|c|c|c|c|c|c|c|c|c|c|c|c|}
\hline Station & Latitude & Longitude & Layer & {$\left[\mathrm{NO}_{3}^{-}+\mathrm{NO}_{2}^{-}\right]$} & {$\left[\mathrm{NH}_{4}^{+}\right]$} & {$\left[\mathrm{PO}_{4}^{3-}\right]$} & $\mathrm{N}^{*}$ & $\delta^{15} \mathrm{~N}$ & $\delta^{18} \mathrm{O}$ & Salinity & Date \\
\hline \multirow[t]{3}{*}{ A-1 } & 32.91 & 124.59 & $17^{*}$ & 3.8 & 0.8 & 0.1 & 5.9 & 7.7 & 7.8 & 30.11 & Jul 09 \\
\hline & & & 30 & 11.9 & 0.0 & 0.6 & 5.2 & 6.2 & 3.9 & 32.67 & \\
\hline & & & $61(67)$ & 11.9 & 0.1 & 0.6 & 5.3 & 6.1 & 4.3 & 32.77 & \\
\hline \multirow[t]{4}{*}{ A-5 } & 32.92 & 125.50 & 10 & 2.5 & 0.2 & 0.0 & 5.6 & 7.5 & 7.8 & 29.89 & Jul 09 \\
\hline & & & 30 & 10.4 & 0.0 & 0.4 & 6.9 & 7.4 & 5.6 & 32.41 & \\
\hline & & & 60 & 11.3 & 0.1 & 0.8 & 1.5 & 6.7 & 4.6 & 33.23 & \\
\hline & & & $89(92)$ & 11.4 & 0.0 & 0.8 & 1.5 & 6.7 & 4.5 & 33.24 & \\
\hline \multirow[t]{2}{*}{ A-11 } & 32.91 & 127.00 & 50 & 7.6 & 0.0 & 0.4 & 4.1 & 7.1 & 3.8 & 33.98 & Jul 09 \\
\hline & & & 102 & 11.0 & 0.1 & 0.8 & 1.2 & 6.0 & 2.9 & 34.48 & \\
\hline \multirow[t]{5}{*}{ B-1 } & 32.50 & 124.59 & 0 & 2.4 & 0.3 & 0.0 & 5.6 & 12.7 & 13.4 & 29.14 & Jul 09 \\
\hline & & & 10 & 3.3 & 0.6 & 0.1 & 5.2 & 12.0 & 11.2 & 29.48 & \\
\hline & & & $15^{*}$ & 5.3 & 0.5 & 0.0 & 8.7 & 9.6 & 6.6 & 29.85 & \\
\hline & & & 30 & 14.1 & 0.0 & 0.3 & 12.2 & 7.8 & 5.0 & 31.04 & \\
\hline & & & $40(47)$ & 14.9 & 0.1 & 0.4 & 11.5 & 7.3 & 5.5 & 31.17 & \\
\hline \multirow[t]{2}{*}{ B-5 } & 32.50 & 125.50 & 30 & 9.4 & 0.1 & 0.3 & 7.6 & 7.8 & 6.3 & 32.24 & Jul 09 \\
\hline & & & $70.5(75)$ & 11.0 & 0.1 & 0.7 & 2.8 & 6.9 & 5.1 & 32.93 & \\
\hline \multirow[t]{3}{*}{ B-11 } & 32.52 & 127.00 & 40 & 5.1 & 0.1 & 0.4 & 1.7 & 6.4 & 5.2 & 34.48 & Jul 09 \\
\hline & & & 75 & 6.4 & 0.1 & 0.4 & 3.0 & 5.8 & 3.5 & 34.01 & \\
\hline & & & $115(122)$ & 11.5 & 0.1 & 0.9 & 0.1 & 5.7 & 4.1 & 34.57 & \\
\hline \multirow[t]{2}{*}{ D-5 } & 31.78 & 125.50 & $15^{*}$ & 2.4 & 0.5 & 0.0 & 5.6 & 10.5 & 12.8 & 31.52 & Jul 09 \\
\hline & & & $55(59)$ & 11.5 & 0.0 & 0.5 & 6.4 & 6.8 & 5.5 & 32.19 & \\
\hline \multirow[t]{4}{*}{ D-6 $6^{\prime}$} & 31.78 & 125.83 & $18^{*}$ & 3.3 & 0.3 & 0.0 & 6.3 & 13.2 & 15.8 & 31.67 & Jul 09 \\
\hline & & & 30 & 11.2 & 0.0 & 0.4 & 7.7 & 7.1 & 6.0 & 32.17 & \\
\hline & & & 50 & 11.8 & 0.0 & 0.6 & 5.1 & 6.5 & 5.0 & 32.53 & \\
\hline & & & $60(68)$ & 11.0 & 0.0 & 0.6 & 4.3 & 6.2 & 5.0 & 32.74 & \\
\hline \multirow[t]{3}{*}{ D-7' } & 31.78 & 126.17 & $22^{*}$ & 9.2 & 0.2 & 0.4 & 5.9 & 14.7 & 15.6 & 31.85 & Jul 09 \\
\hline & & & 30 & 3.3 & 0.0 & 0.0 & 6.0 & 7.9 & 7.4 & 32.34 & \\
\hline & & & $70(76)$ & 8.1 & 0.0 & 0.5 & 3.0 & 6.2 & 3.8 & 33.26 & \\
\hline \multirow[t]{2}{*}{ D-9 } & 31.78 & 126.50 & 50 & 5.7 & 0.1 & 0.4 & 2.3 & 5.7 & 2.4 & 33.69 & Jul 09 \\
\hline & & & $90(95)$ & 10.9 & 0.0 & 0.8 & 1.0 & 5.6 & 3.1 & 34.26 & \\
\hline \multirow[t]{3}{*}{ D-10' } & 31.78 & 126.83 & $33^{*}$ & 2.6 & 0.0 & 0.2 & 2.3 & 8.6 & 7.2 & 33.67 & Jul 09 \\
\hline & & & 60 & 7.0 & 0.1 & 0.5 & 2.0 & 5.4 & 2.3 & 33.96 & \\
\hline & & & $90(100)$ & 11.1 & 0.0 & 0.8 & 1.2 & 5.1 & 2.3 & 34.38 & \\
\hline \multirow[t]{3}{*}{ D-12' } & 31.78 & 127.17 & 50 & 8.8 & 0.1 & 0.6 & 2.2 & 5.9 & 3.0 & 34.08 & Jul 09 \\
\hline & & & 75 & 9.1 & 0.0 & 0.6 & 2.4 & 5.4 & 2.3 & 34.15 & \\
\hline & & & $115(121)$ & 12.1 & 0.0 & 0.9 & 0.6 & 5.0 & 3.1 & 34.54 & \\
\hline \multirow[t]{2}{*}{ D-13 } & 31.78 & 127.50 & 75 & 7.8 & 0.5 & 0.6 & 1.6 & 5.2 & 3.8 & 34.54 & Jul 09 \\
\hline & & & $120(132)$ & 13.3 & 0.0 & 0.9 & 1.8 & 5.4 & 3.9 & 34.54 & \\
\hline \multirow[t]{4}{*}{ D-16 } & 31.78 & 128.75 & $75^{*}$ & 1.8 & 0.1 & 0.2 & 1.6 & 6.8 & 6.3 & 34.46 & Jul 09 \\
\hline & & & 125 & 6.2 & 0.0 & 0.5 & 1.1 & 5.1 & 4.4 & 34.52 & \\
\hline & & & 200 & 11.6 & 0.0 & 0.8 & 1.7 & 5.6 & 3.5 & 34.54 & \\
\hline & & & $750(770)$ & 34.9 & 0.1 & 2.5 & -2.1 & 5.7 & 2.5 & 34.37 & \\
\hline
\end{tabular}


Table 3. Nitrate concentration and $\delta^{15} \mathrm{~N}$ and $\delta^{18} \mathrm{O}$ in nitrate at each layer of the sampling stations in July, 2011. The depth (m) in parentheses indicates the water depth, and the layers with asterisks are the chlorophyll maximum.

\begin{tabular}{|c|c|c|c|c|c|c|c|c|c|c|c|}
\hline Station & Latitude & Longitude & Layer & {$\left[\mathrm{NO}_{3}^{-}+\mathrm{NO}_{2}^{-}\right]$} & {$\left[\mathrm{NH}_{4}^{+}\right]$} & {$\left[\mathrm{PO}_{4}^{3-}\right]$} & $\mathrm{N}^{*}$ & $\delta^{15} \mathrm{~N}$ & $\delta^{18} \mathrm{O}$ & Salinity & Date \\
\hline \multirow[t]{4}{*}{$\mathrm{C}-1$} & 32.26 & 124.63 & 0 & 27.1 & 0.5 & 0.0 & 30.3 & 12.8 & 8.9 & 23.51 & Jul 11 \\
\hline & & & $13.4^{*}$ & 2.3 & 0.2 & 0.0 & 5.1 & 18.0 & 20.3 & 31.26 & \\
\hline & & & 20 & 12.4 & 0.2 & 0.2 & 12.8 & 7.0 & 6.4 & 31.70 & \\
\hline & & & $40.9(44)$ & 12.0 & 0.3 & 0.3 & 10.7 & 6.9 & 6.6 & 31.78 & \\
\hline \multirow[t]{3}{*}{$\mathrm{C}-3$} & 32.25 & 125.00 & 0 & 24.8 & 0.7 & 0.0 & 28.2 & 13.8 & 9.7 & 23.07 & Jul 11 \\
\hline & & & $14.9^{*}$ & 10.1 & 0.2 & 0.0 & 12.5 & 8.4 & 7.7 & 31.85 & \\
\hline & & & $46.8(51)$ & 13.5 & 0.2 & 0.6 & 7.6 & 6.4 & 5.2 & 32.37 & \\
\hline \multirow[t]{5}{*}{ C-5 } & 32.25 & 125.51 & 0 & 7.6 & 0.6 & 0.0 & 10.8 & 13.7 & 14.8 & 29.30 & Jul 11 \\
\hline & & & 10 & 4.4 & 0.4 & 0.0 & 7.4 & 14.8 & 15.9 & 30.07 & \\
\hline & & & $25.5^{*}$ & 6.5 & 0.2 & 0.1 & 8.7 & 11.5 & 11.6 & 32.47 & \\
\hline & & & 40 & 8.7 & 0.2 & 0.5 & 4.3 & 7.2 & 6.7 & 33.33 & \\
\hline & & & 67.3(69) & 8.6 & 0.2 & 0.5 & 3.4 & 7.2 & 6.4 & 33.49 & \\
\hline \multirow[t]{2}{*}{ C-9 } & 32.25 & 126.50 & 0 & 2.5 & 0.4 & 0.0 & 5.5 & 21.6 & 23.4 & 30.35 & Jul 11 \\
\hline & & & 107(109) & 8.4 & 0.1 & 0.5 & 3.2 & 6.4 & 4.6 & 33.80 & \\
\hline \multirow[t]{6}{*}{ D-4' } & 31.76 & 125.34 & 3 & 2.2 & 0.8 & 0.5 & -2.8 & 17.0 & 21.9 & 30.59 & Jul 11 \\
\hline & & & 10 & 2.0 & 0.7 & 0.0 & 5.3 & 16.1 & 20.7 & 31.29 & \\
\hline & & & $16.4^{*}$ & 2.3 & 1.0 & 0.0 & 6.0 & 11.3 & 11.7 & 32.32 & \\
\hline & & & 30 & 11.0 & 0.5 & 0.0 & 14.1 & 11.8 & 6.7 & 32.54 & \\
\hline & & & 40 & 10.9 & 0.5 & 0.1 & 13.5 & 6.2 & 5.5 & 32.59 & \\
\hline & & & $50.1(55)$ & 11.2 & 0.1 & 0.5 & 6.2 & 6.0 & 5.2 & 32.61 & \\
\hline \multirow[t]{2}{*}{ D-6' } & 31.75 & 125.83 & 50 & 8.5 & 0.5 & 0.5 & 3.6 & 7.4 & 6.2 & 33.51 & Jul 11 \\
\hline & & & $63.3(68)$ & 8.6 & 0.8 & 0.5 & 3.6 & 6.8 & 6.0 & 33.53 & \\
\hline \multirow[t]{3}{*}{ D-7' } & 31.75 & 126.17 & $25^{*}$ & 2.3 & 0.5 & 0.1 & 4.1 & 11.4 & 11.9 & 33.44 & Jul 11 \\
\hline & & & 50 & 8.9 & 0.5 & 0.6 & 3.3 & 6.5 & 5.9 & 33.57 & \\
\hline & & & $72.9(77)$ & 8.9 & 1.0 & 0.6 & 3.7 & 7.4 & 6.2 & 33.58 & \\
\hline \multirow[t]{2}{*}{ D-9 } & 31.75 & 126.50 & 50 & 8.3 & 0.3 & 0.5 & 3.3 & 6.6 & 5.5 & 33.73 & Jul 11 \\
\hline & & & $92.9(97)$ & 7.6 & 0.8 & 0.5 & 3.5 & 6.7 & 5.6 & 33.73 & \\
\hline \multirow[t]{2}{*}{ D-11 } & 31.75 & 127.00 & $4^{*}$ & 3.1 & 1.0 & 0.0 & 6.7 & 20.0 & 19.3 & 30.30 & Jul 11 \\
\hline & & & 104(109) & 8.4 & 0.3 & 0.5 & 3.3 & 6.2 & 4.3 & 33.94 & \\
\hline \multirow[t]{5}{*}{ D-13 } & 31.75 & 127.50 & $27.5^{*}$ & 0.9 & 0.7 & 0.0 & 4.2 & 21.7 & 25.0 & 33.73 & Jul 11 \\
\hline & & & 30 & 2.8 & 0.3 & 0.1 & 5.0 & 12.4 & 12.8 & 33.82 & \\
\hline & & & 50 & 9.6 & 0.2 & 0.6 & 2.5 & 5.4 & 3.1 & 34.51 & \\
\hline & & & 100 & 12.7 & 0.2 & 0.9 & 1.7 & 5.8 & 3.3 & 34.64 & \\
\hline & & & $129(132)$ & 12.9 & 0.2 & 0.9 & 2.2 & 5.7 & 3.4 & 34.55 & \\
\hline \multirow[t]{6}{*}{ D-16 } & 31.75 & 128.75 & $65^{*}$ & 1.50 & 0.4 & 0.1 & 2.5 & 9.3 & 10.8 & 34.41 & Jul 11 \\
\hline & & & 100 & 5.8 & 1.2 & 0.4 & 4.1 & 5.1 & 4.0 & 34.45 & \\
\hline & & & 200 & 9.4 & 0.2 & 0.7 & 1.8 & 5.5 & 4.0 & 34.57 & \\
\hline & & & 400 & 18.9 & 0.3 & 2.1 & -11.2 & 5.9 & 4.5 & 34.37 & \\
\hline & & & 600 & 32.4 & 0.5 & 2.8 & -9.1 & 6.0 & 2.7 & 34.37 & \\
\hline & & & $759(770)$ & 34.3 & 1.0 & 2.8 & -6.6 & 6.2 & 2.5 & 34.38 & \\
\hline
\end{tabular}

the SMW in winter. Because $\mathrm{NO}_{3}$ is not actively taken up by phytoplankton during winter (Chen et al., 2001) and so tends to behave as a conservative parameter, the relationship between salinity and $\mathrm{NO}_{3}$ also indicates that YSMW and $\mathrm{KSSW}$ are the main sources of $\mathrm{NO}_{3}$ in the SMW (Fig. 7a).
Generally, in summer, in the surface ECS water, TWCW intensifies gradually while the Kuroshio intrusion weakens (Guo et al., 2006), and a buoyant plume of CDW disperses eastward and reaches as far as the shelf edge with a 2-month time lag from the time of discharge at the river mouth (Isobe and Matsuno, 2008; Yamaguchi et al., 2012). However, the 
a)

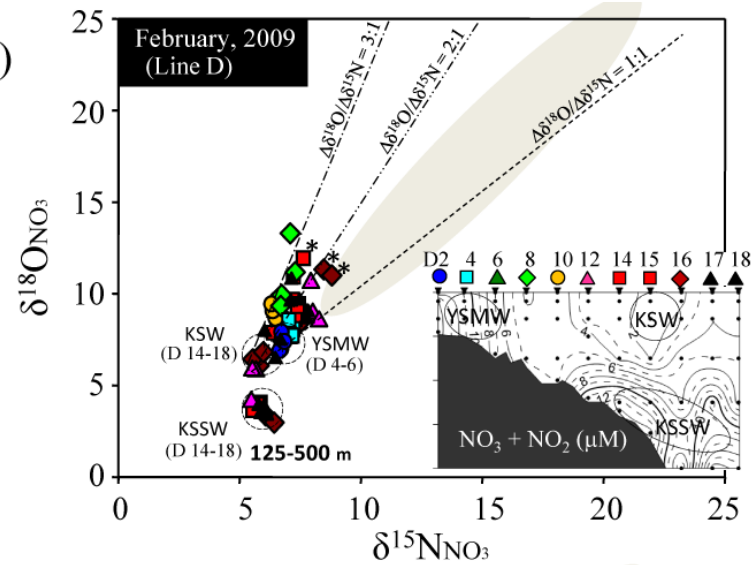

b)

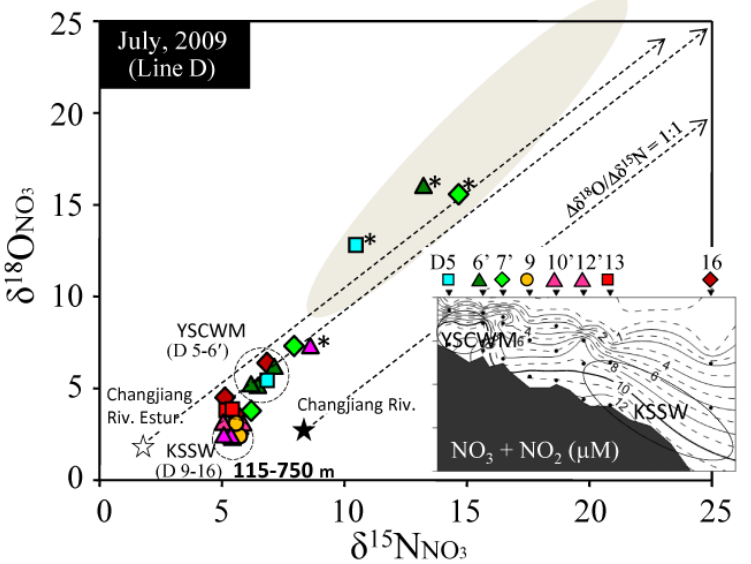

c)

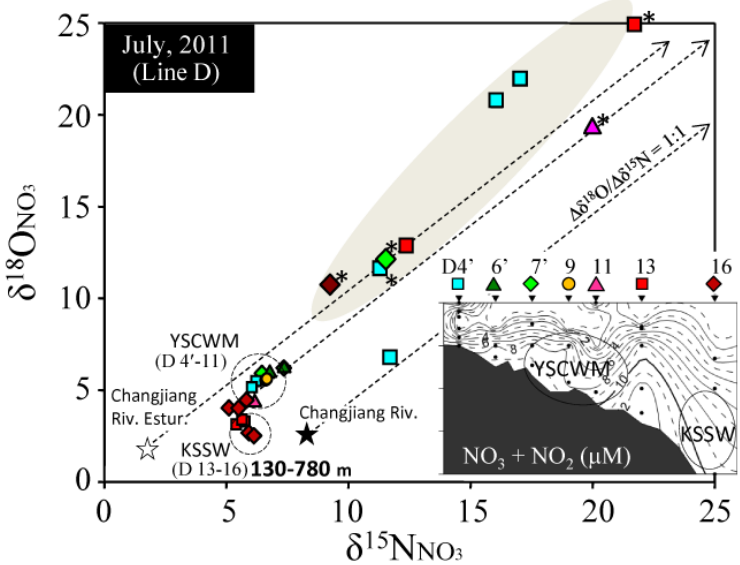

Fig. 4. Relationship between $\delta^{18} \mathrm{O}$ and $\delta^{15} \mathrm{~N}$ in nitrate collected at each location along transect D in (a) February 2009, (b) July 2009, and (c) July 2011. The symbols with asterisk (*) are the samples collected at the layer of chlorophyll maximum. The dotted line and the two-dot chain line indicate the lines of $\Delta \delta^{18} \mathrm{O}: \Delta \delta^{15} \mathrm{~N}=1: 1$ and $2: 1$, respectively. The closed and open stars indicate $\delta^{15} \mathrm{~N}$ and $\delta^{18} \mathrm{O}$ values in the lower stream of the Changjiang River and Changjiang River Estuary, reported by Li et al. (2010) and Chen et al. (2013), respectively. Oval hatch indicates the range of $\delta^{15} \mathrm{~N}$ and $\delta^{18} \mathrm{O}$ in $\mathrm{NO}_{3}$ observed in the Changjiang River Estuary and adjacent western ECS $\left(31-33^{\circ} \mathrm{N}, 122-126^{\circ} \mathrm{E}\right)$ reported in Chen et al. (2013). a)

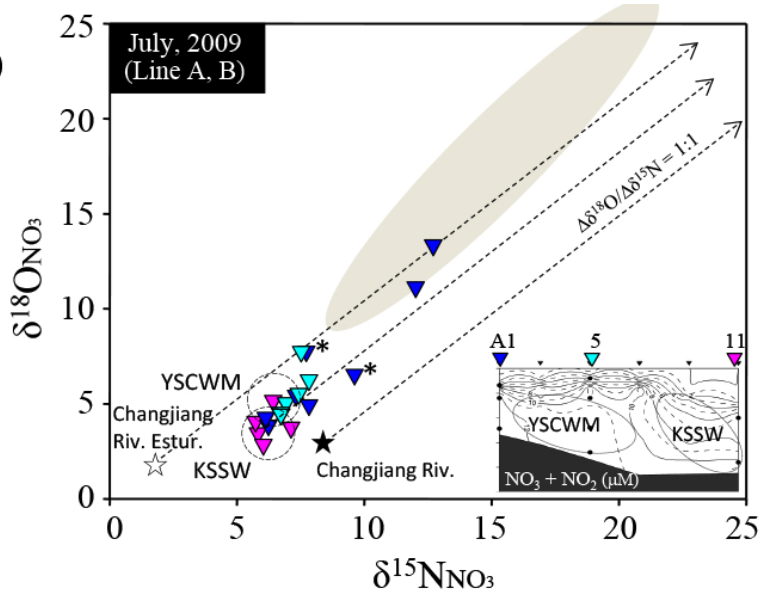

b)

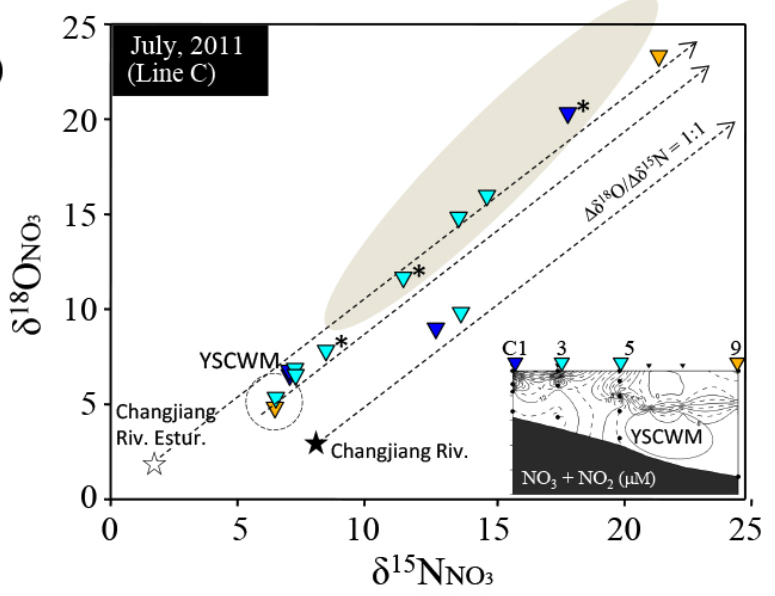

Fig. 5. Relationship between $\delta^{18} \mathrm{O}$ and $\delta^{15} \mathrm{~N}$ in nitrate collected at each location along (a) transects A and B in July 2009 and (b) transect $\mathrm{C}$ in July 2011. The symbols and lines in the figure are the same as in Fig. 4. The cross section of transect B is omitted.

formation of SMW from the surface to the bottom in the northern ECS in summer was very complex in our surveys and varied year by year. In July 2011, the YSCWM spread eastward in the northern ECS, and a higher-density water mass (i.e., $\sigma_{T}=25.5$ ) was largely present from the bottom to the middle layer as compared to the water mass (i.e., $\sigma_{T}=24.5$ ) during the same period in 2009 (Figs. 2h-i, 3i$1,6 \mathrm{~b}, \mathrm{c})$. The relatively lower-density water mass of 2009 seemed to have originated from mixing between the shelf bottom water and surrounding water masses of lower density (i.e., mix with CDW and KSSW as suggested by ovals no. 1 and no. 5, respectively, in Fig. 6b). The contribution of KSSW-derived $\mathrm{NO}_{3}$ in the shelf bottom water to upper $\mathrm{NO}_{3}$ pool in the SMW may be activated by vertical eddy diffusion and intermittent turbulence associated with internal waves (Matsuno et al., 1994, 2006). Shiozaki et al. (2011) 

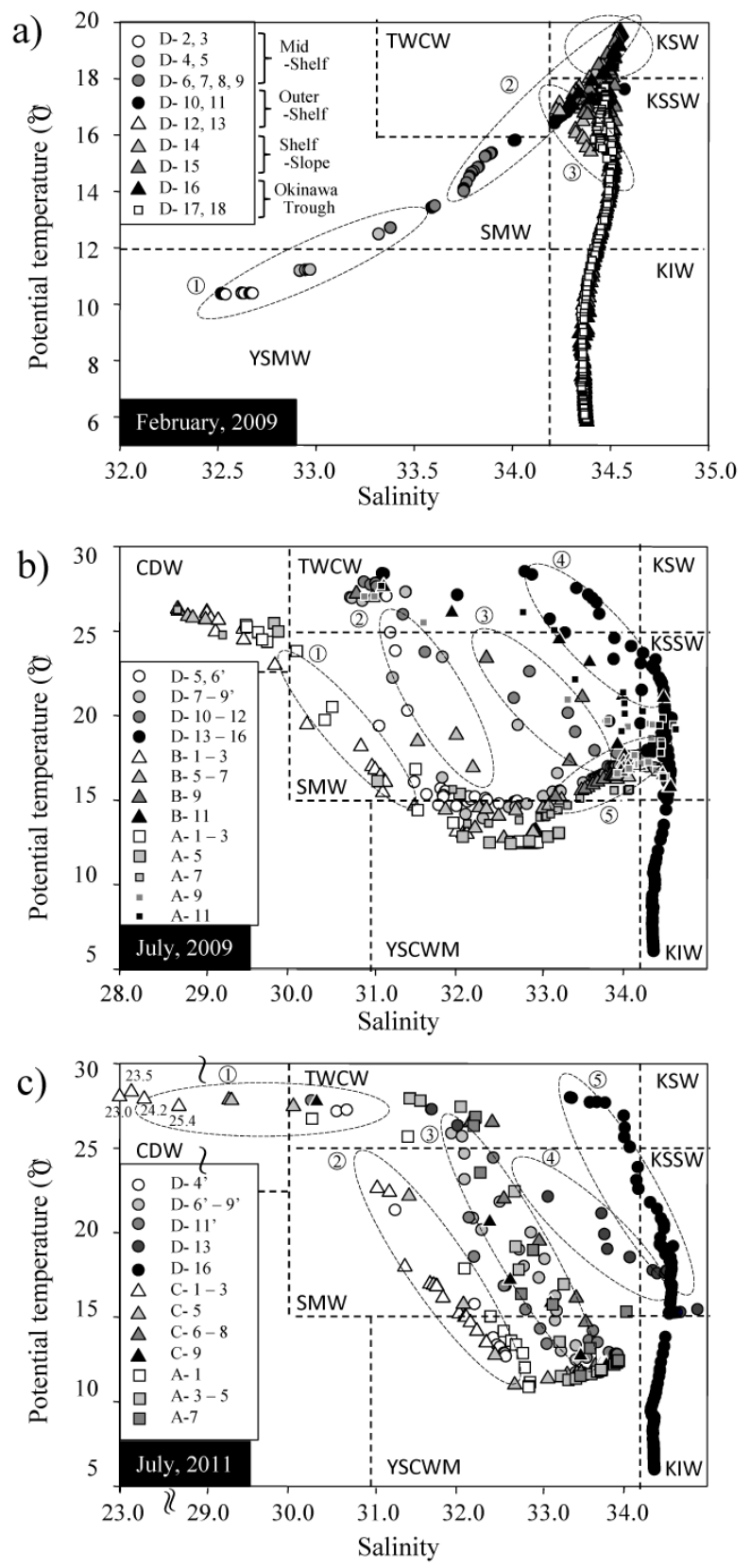

Fig. 6. Plot of salinity-temperature data collected from the surface to the bottom at each station in (a) February 2009, (b) July 2009, and (c) July 2011. The typical salinity-temperature ranges of each water mass - Kuroshio Surface Water (KSW), Kuroshio Subsurface Water (KSSW), Kuroshio Intermediate Water (KIW), Taiwan Warm Current Water (TWCW), Changjiang Diluted Water (CDW), Yellow Sea Cold Water Mass (YSCWM), Yellow Sea Mixed Water (YSMW) and shelf mixed water (SMW) - are from Zhu et al. (2004), Zhang et al. (2007a, b, 2008), and Chen (2008). The oval circles of the dotted line with numbers show the potential mixing of different water masses, which can be partly enhanced by turbulence and diffusive convection. Low-salinity waters that were out of range are additionally depicted with salinity values in (c). estimated that the diapycnal $\mathrm{NO}_{3}$ flux associated with these physical processes was 64 to $1200 \mu$ mol- $\mathrm{N} \mathrm{m}^{-2} \mathrm{~d}^{-1}$ in the ECS. Unlike the situation in 2009, KSSW did not make direct contact with YSCWM on the shelf in 2011 but contacted TWCW-origin surface water around the shelf-slope area (i.e., ovals no. 4 and no. 5 in Figure 6c). The Kuroshio onshore flux, which merges with TSWW northeast of Taiwan and along the shelf-slope southwest of Kyusyu (Lee and Matsuno, 2007), shows strong seasonal variation with a minimum $(0.5 \mathrm{~Sv})$ in summer and a maximum $(3 \mathrm{~Sv})$ in autumn (Guo et al., 2006). Considering this seasonal change in the onshore flux and the fact that the southern YSCWM develops in summer and decays in fall (Zhang et al., 2008), the results of this study may provide evidence that the annual shift in the southern YSCWM development in summer controls the relative contribution of KSSW-derived nutrients to the SMW during summer. The distribution of the YSCWM is associated with the circulation of waters in the Yellow Sea (YS) and ECS generated by the monsoon and the tidal currents (Moon et al., 2009). The sea level increase in the northern areas of the YS due to the southeasterly summer monsoon winds and intrusion of TWCW into surface YS generates the compensation movement, a southward flow at the bottom water (Jacobs et al., 2000; Zhang et al., 2008). Therefore the southward spreading of YSCWM during summer can be affected by the strength of the southerly summer monsoon winds and velocity of TWCW. On the other hand, interannual variations of the Kuroshio intrusion flux at a lower layer of continental shelf is reported to be strongly influenced by wind-forced variations in the interior North Pacific, which propagates westward as long Rossby waves (Li et al., 2013). Although it is likely that the stronger southerly summer monsoon also stimulates KSSW intrusion onto the shelf due to compensation of eastward surface Ekman transport, the exact mechanisms involved in the combination of remote and local forcing among the years remain to be clarified.

In July 2011, the buoyant plume of CDW traveled farther offshore and mixed with warm TWCW (i.e., oval no. 1 in Fig. 6c) and then gradually mixed with bottom YSCWM (ovals no. 2 and no. 3 in Fig. 6c). China suffered from severe drought during most seasons of 2009, but a series of floods occurred in central China, Changjiang River Basin, from June to September 2011 (World Meteorological Organization, 2009, 2011). The different freshwater discharges from the Changjiang River in 2009 and 2011 could be another factor controlling the formation of SMW and potential sources of $\mathrm{NO}_{3}$ during summer, as well as YSCWM development.

Unlike the case in winter, there was no clear relationship between salinity and $\mathrm{NO}_{3}$ concentrations in summer (Fig. 7b and c). This observation is probably explained by several reasons: (1) nutrients did not behave as conservative parameters during summer because of active uptake by phytoplankton; (2) $\mathrm{NO}_{3}$ concentrations in the Changjiang River, which is one of the main nutrient sources of the northern ECS in summer, 
varied with time; and (3) in addition to the mixing of multiple water masses suggested by the $T-S$ diagram, higher temperatures might have stimulated bacterial remineralization in the water column and surface sediment and subsequent nitrification (see below).

\subsection{Nitrate dynamics and identification of new nitrate that supports phytoplankton growth based on $\delta^{15} \mathrm{~N}$ in nitrate}

Our estimated contributions of each water mass to the SMW provide information on the potential sources of $\mathrm{NO}_{3}$. However, this does not necessarily indicate that the $\mathrm{NO}_{3}$ would in fact stimulate and sustain phytoplankton growth, partly because of low concentrations (and flux) of nutrients and/or other limiting factors such as light, phosphorus, or trace metals. Hence, we attempted to identify the sources of $\mathrm{NO}_{3}$ to the northern ECS that were newly supplied from outside the system and actually used by phytoplankton in winter and summer based on information on $\mathrm{NO}_{3}$ isotopes.

$\delta^{15} \mathrm{~N}_{\mathrm{NO}_{3}}$ and $\delta^{18} \mathrm{O}_{\mathrm{NO}_{3}}$ at a depth of 200 to $300 \mathrm{~m}$ below the euphotic zone in the Okinawa Trough (i.e., KSSW, $\delta^{15} \mathrm{~N}=5.5-6.0 \%, \delta^{18} \mathrm{O}=3.5-4.0 \%$ o, $\left[\mathrm{NO}_{3}\right]=10-$ $25 \mu \mathrm{M}$, salinity $=34.4-34.6$ ) were almost steady year-round, even compared to the values in deep Kuroshio water (i.e., $\delta^{15} \mathrm{~N}=5.5-6.1 \%$, below $500 \mathrm{~m}$ northeast of Taiwan) collected 20 years ago in July 1992 (Liu et al., 1996). Furthermore, $\delta^{15} \mathrm{~N}_{\mathrm{NO}_{3}}$ and $\delta^{18} \mathrm{O}_{\mathrm{NO}_{3}}$ in deep KSSW were distinct from those of other major $\mathrm{NO}_{3}$ sources, such as the Changjiang River (i.e., $\delta^{15} \mathrm{~N}=8.3 \%$ o, $\delta^{18} \mathrm{O}=2.6 \%$, $\left[\mathrm{NO}_{3}\right]=66.7 \mu \mathrm{M}$, salinity $=0$; river water collected at Zhangjiagang from the lower stream of the Changjiang River, $\mathrm{Li}$ et al., 2010; $\delta^{15} \mathrm{~N}=2.0 \%$ o, $\delta^{18} \mathrm{O}=1.9 \%$, $\left[\mathrm{NO}_{3}\right]=13.0$ $15.0 \mu \mathrm{M}$, salinity $=31.0-32.0$; sea water collected at Changjiang River Estuary, Chen et al., 2013), and $\mathrm{NO}_{3}$ from wet deposition (i.e., $\delta^{15} \mathrm{~N}=-0.4 \pm 2.9 \%$, $\delta^{18} \mathrm{O}=73.3 \pm 9.8 \%$ o, $\left[\mathrm{NO}_{3}\right]=35.9 \pm 44.4 \mu \mathrm{M}, \quad$ salinity $=0$ $[\mathrm{n}=47]$; Nagasaki City location facing the ECS, Y. Umezawa, unpublished data). The differences among these values of potential $\mathrm{NO}_{3}$ sources can be useful for tracing the contribution of each $\mathrm{NO}_{3}$ source, assuming that any changes in $\delta^{15} \mathrm{~N}_{\mathrm{NO}_{3}}$ and $\delta^{18} \mathrm{O}_{\mathrm{NO}_{3}}$ by biological and physical activities during transportation are correctly compensated for. Levels of $\delta^{15} \mathrm{~N}_{\mathrm{NO}_{3}}$ and $\delta^{18} \mathrm{O}_{\mathrm{NO}_{3}}$ in the northern ECS seemed to be higher in the chlorophyll maximum irrespective of season and year (Figs. 4 and 5). In addition, the ratio of enrichment of heavier $\mathrm{O}$ and $\mathrm{N}$ isotopes from the potential $\mathrm{NO}_{3}$ sources (i.e., $\Delta \delta^{18} \mathrm{O}: \Delta \delta^{15} \mathrm{~N}$ ) was about 1.0 in summer and spread over the range from 1.0 to 3.0 in winter, although the reported ${ }^{18} \varepsilon:{ }^{15} \varepsilon$ associated with $\mathrm{NO}_{3}$ assimilation by eukaryotic phytoplankton is almost 1.0 under incubation conditions (Granger et al., 2004). Therefore, isotopic fractionation during $\mathrm{NO}_{3}$ uptake by phytoplankton was expected to be a major factor causing changes in $\delta^{15} \mathrm{~N}_{\mathrm{NO}_{3}}$ and $\delta^{18} \mathrm{O}_{\mathrm{NO}_{3}}$ in the
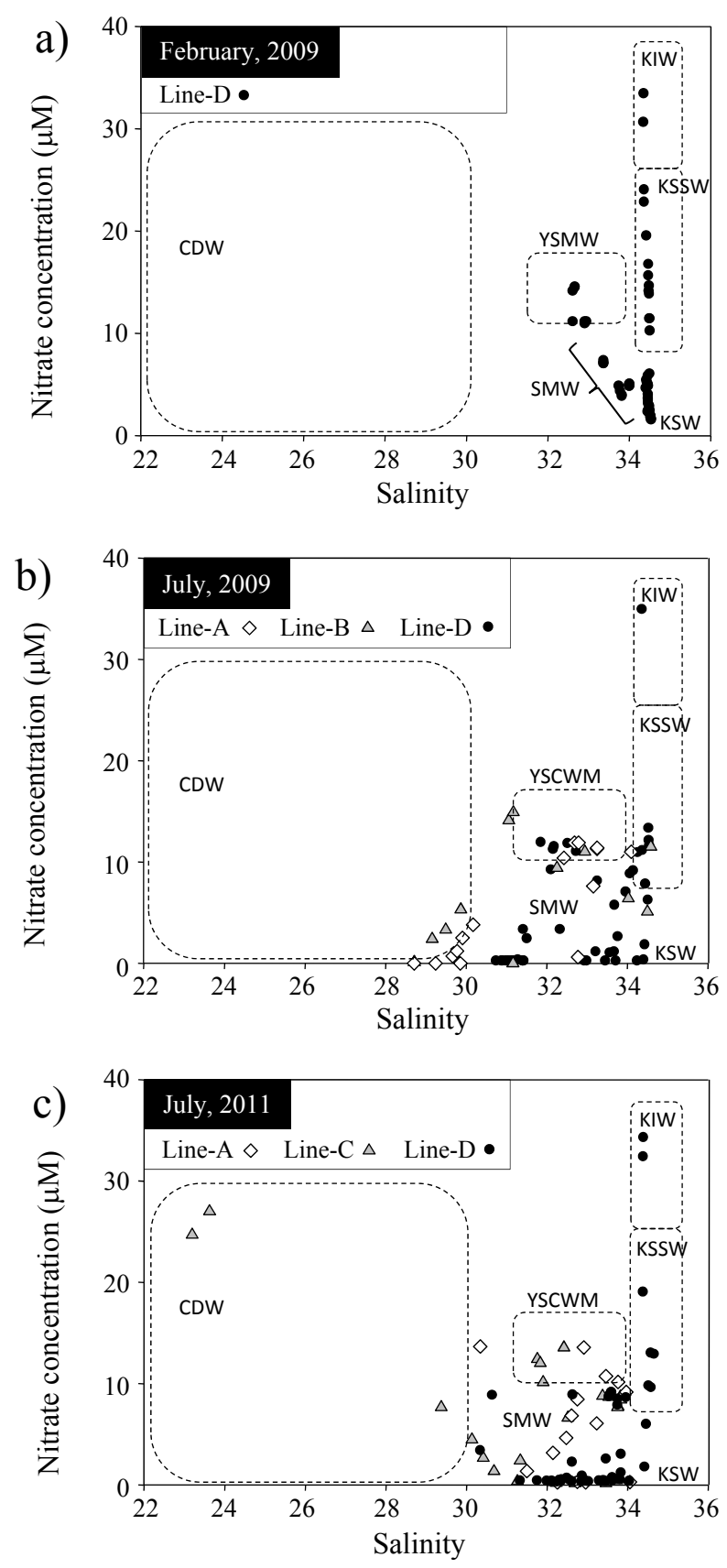

Fig. 7. Relationship between salinity and nitrate concentration in the northern ECS in (a) February 2009, (b) July 2009, and (c) July 2011. The abbreviations of water masses are the same as those in Fig. 6.

northern ECS at least during summer, but other factors can also modify the values.

First, as a basis for discussion, $\delta^{15} \mathrm{~N}_{\mathrm{NO}_{3}}$ values were plotted as a function of the log-transformed $\mathrm{NO}_{3}$ concentration (i.e., $\ln \left[\mathrm{NO}_{3}\right]$ ) to investigate the effect of phytoplankton uptake on $\delta^{15} \mathrm{~N}$ in $\mathrm{NO}_{3}$ (Figs. 8 and 9). When $\mathrm{NO}_{3}$ is biologically consumed following a Rayleigh fractionation model in 

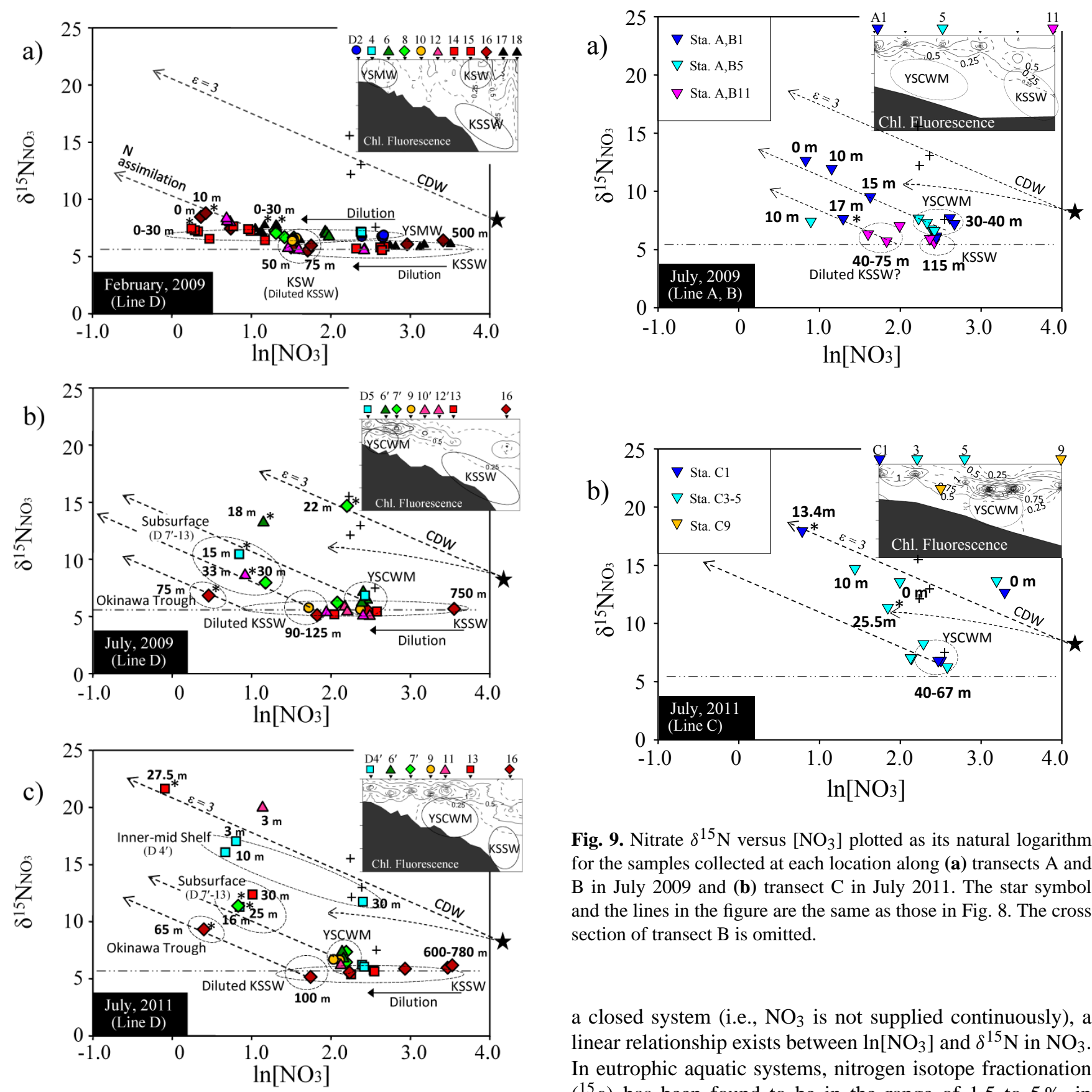

Fig. 9. Nitrate $\delta^{15} \mathrm{~N}$ versus $\left[\mathrm{NO}_{3}\right]$ plotted as its natural logarithm for the samples collected at each location along (a) transects $\mathrm{A}$ and B in July 2009 and (b) transect C in July 2011. The star symbol and the lines in the figure are the same as those in Fig. 8. The cross section of transect B is omitted.

Fig. 8. Nitrate $\delta^{15} \mathrm{~N}$ versus $\left[\mathrm{NO}_{3}\right]$ plotted as its natural logarithm for the samples collected at each location along transect D in (a) February 2009, (b) July 2009, and (c) July 2011. The numerical values near the symbols indicate water depth at locations where water was sampled, and other symbols are as those in Fig. 4. The cross symbols are $\delta^{15} \mathrm{~N}_{\mathrm{NO}_{3}}-\ln \left[\mathrm{NO}_{3}\right]$ collected in the Changiiang Estuary and adjacent ECS, where active phytoplankton uptake was observed (Chen et al., 2013). The dotted straight lines and a curved line indicate the expected shift in $\delta^{15} \mathrm{~N}$ associated with $\mathrm{NO}_{3}$ assimilation following the Rayleigh model $(\varepsilon=3.0)$ and the steady-state model $(\varepsilon=3.0)$, respectively (see Fig. 10). The two-dot chain line indicates the $\delta^{15} \mathrm{~N}_{\mathrm{NO}_{3}}$ of the deep KSSW. 
Changjiang River plumes and the intrusion of KSSW (Furuya et al., 2003; Chiang et al., 2004). Moreover, in recent years, the dinoflagellate Prorocentrum spp. has been frequently observed on the continental shelf, especially from spring to summer (Dai et al., 2013; Kiyomoto et al., 2013). Nitrogen isotope fractionation $\left({ }^{15} \varepsilon\right)$ during $\mathrm{NO}_{3}$ assimilation by these phytoplankton has been reported to be variable in culture conditions (e.g., 5.6-13.5\%o for Thalassiosira spp., $2.7 \%$ for Chaetoceros spp., and 2.2-5.4\%o for Synechococcus spp.; Waser et al., 1998; Needoba et al., 2003; Granger et al., 2004, 2010). Although several ${ }^{15} \varepsilon$ values (i.e., ${ }^{15} \varepsilon=0$, 3,6 ) were tested for interpretation of the observational data (Fig. 10), ${ }^{15} \varepsilon=3$ was provisionally applied as a representative value in the following discussion. The expected lines along which $\delta^{15} \mathrm{~N}$ in $\mathrm{NO}_{3}$ remaining in the water column after biological uptake would shift from the initial $\delta^{15} \mathrm{~N}_{\mathrm{NO}_{3}}$ are shown in the $\delta^{15} \mathrm{~N}_{\mathrm{NO}_{3}}-\ln \left[\mathrm{NO}_{3}\right]$ diagram (Figs. 8 and 9). A linear relationship between these parameters in the natural environment provides evidence of actual biological uptake of $\mathrm{NO}_{3}$ with some extent of isotopic fractionation, under the assumption that new $\mathrm{NO}_{3}$ is supplied in pulses or water parcels such that $\mathrm{NO}_{3}$ is consumed in a quasi-closed system. When $\mathrm{NO}_{3}$ from the Changjiang River spreads out in a buoyant plume in the nutrient-depleted surface water, the closed system model is more applicable. On the other hand, in the subsurface layer where new $\mathrm{NO}_{3}$ can be continuously supplied from the bottom layer by upward diffusion flux and upwelling, phytoplankton can take up new $\mathrm{NO}_{3}$ as well as $\mathrm{NO}_{3}$ remaining in the pool (e.g., Sigman et al., 1999). Therefore, a steady-state model (Fig. 10) should also be considered in addition to the Rayleigh model because natural systems often cannot be described with only a single model (Figs. 8 and 9).

In winter (February 2009), $\delta^{15} \mathrm{~N}_{\mathrm{NO}_{3}}$ (ca. 6.0\%) in the deep layer of the Okinawa Trough (Sta. D17, 18) and adjacent shelf-slope (Sta. D15, 16) was nearly constant, while $\mathrm{NO}_{3}$ concentrations in the shelf-slope region gradually decreased from the original deeper depth value (Fig. 8a). This phenomenon likely indicates dilution of $\mathrm{NO}_{3}$-rich $\mathrm{KSSW}$ by $\mathrm{NO}_{3}$-depleted KSW (Gong et al., 1996) because $\mathrm{NO}_{3}$ reduction associated with phytoplankton uptake is improbable below the euphotic zone. Similarly, from the mid-shelf zone (Sta. D2-8) to the outer shelf zone (Sta. D9-14), where the $T-S$ diagram suggested that the water was composed of a mixture of YSMW and KSW (ovals no. 1 and no. 2, Fig. 6a), the YSMW-specific $\delta^{15} \mathrm{~N}_{\mathrm{NO}_{3}}$ (ca. 6.7\%o) in the inner midshelf (Sta. D2) did not change even after gradual mixing with the $\mathrm{NO}_{3}$-depleted KSW (Fig. 8a). Low light- and low temperature-limited primary productivity on the shelf during winter (Chen et al., 2001; Chiang et al., 2004; Liu et al., 2010a) could have caused $\mathrm{NO}_{3}$-rich YSMW to experience only dilution with little change in $\delta^{15} \mathrm{~N}_{\mathrm{NO}_{3}}$ due to biological uptake. On the other hand, $\delta^{15} \mathrm{~N}_{\mathrm{NO}_{3}}$ at depths between 0 and $30 \mathrm{~m}$ in the Okinawa Trough and shelf-slope zone increased slightly to $7.8 \%$ (Sta. D17) and $8.8 \%$ (Sta. D16) following the expected fractionation line $(\varepsilon=3)$, which likely

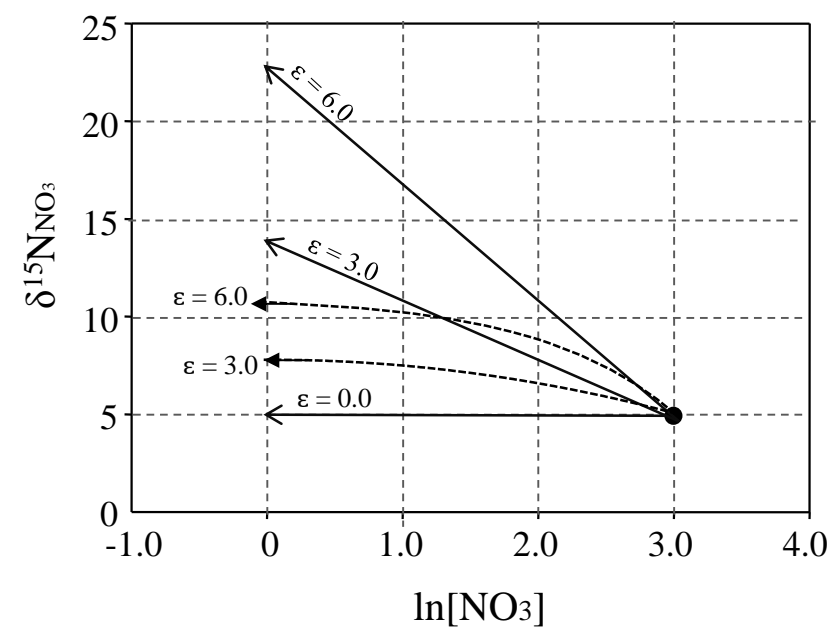

Fig. 10. Examples of the expected $\delta^{15} \mathrm{~N}_{\mathrm{NO}_{3}}$ shift for a given $\left[\mathrm{NO}_{3}\right]$ (plotted as its natural logarithm) for the case of $\varepsilon=0,3.0$, and 6.0, based on both the Rayleigh model (closed system model, solid line) and the steady-state model (open system model, dotted line). When $\mathrm{NO}_{3}$ is assimilated by organisms with isotopic fractionation, initial values (e.g., $\ln \left[\mathrm{NO}_{3}\right]=3.0$ and initial $\delta^{15} \mathrm{~N}_{\mathrm{NO}_{3}}=5.0$ ) will be shifted following Eq. (1) according to the Rayleigh model in the case of a closed system (i.e., new $\mathrm{NO}_{3}$ is not continuously supplied) or following Eq. (2) according to the steady-state model in the case of an open system (i.e., new $\mathrm{NO}_{3}$ is continuously supplied), or, most likely, according to some intermediate condition (e.g., Sigman et al., 1999; Sugimoto et al., 2009).

$\delta^{15} \mathrm{~N}_{\mathrm{NO}_{3}}=$ initial $\delta^{15} \mathrm{~N}_{\mathrm{NO}_{3}}-\varepsilon \times \ln (\delta)$
$\delta^{15} \mathrm{~N}_{\mathrm{NO}_{3}}=$ initial $\delta^{15} \mathrm{~N}_{\mathrm{NO}_{3}}+\varepsilon \times\left(1-\int\right)$,

where $\int$ is the fraction of $\mathrm{NO}_{3}$ remaining in the water column from the initial $\mathrm{NO}_{3}$ concentration, and $\varepsilon$ is the isotopic fractionation factor (in \%o units) for $\mathrm{NO}_{3}$ utilization by organisms.

started from the diluted KSSW (KSW) (Fig. 8a). Because this zone corresponded to the chlorophyll maximum zone, diatom blooms were likely stimulated by increase of transparency and temperature associated with warm KSW and $\mathrm{NO}_{3}$ supply from KSSW. However, shifts in $\delta^{15} \mathrm{~N}_{\mathrm{NO}_{3}}$ were limited compared to those in summer because of lower $\mathrm{NO}_{3}$ uptake by phytoplankton, as discussed above.

During summer (in both 2009 and 2011), $\delta^{15} \mathrm{~N}$ values were again nearly constant from the deep water to middle layer at the Okinawa Trough (i.e., KSSW) and up to the bottom water on the shelf to a different extent in each year (i.e., from the continental slope to the mid-shelf area [Sta. D9] in 2009 (Fig. 4b), but limited to the edge of the outer shelf [Sta. D13] in 2011 (Fig. 4c)), despite a gradual decrease in $\mathrm{NO}_{3}$ concentration, suggesting simple dilution of $\mathrm{NO}_{3}$-rich $\mathrm{KSSW}$ by $\mathrm{NO}_{3}$-depleted KSW (Figs. 8b,c). The trace of KSSW-specific $\delta^{15} \mathrm{~N}$ values (ca. 6.0\% $)$ reinforces the idea that the difference in the expansion of KSSW-derived $\mathrm{NO}_{3}$ to the shelf areas between years was likely controlled by the development of the 
YSCWM, which corresponds with the suggestion from the $T-S$ diagram analysis (Sect. 4.1).

The slight increase in $\delta^{15} \mathrm{~N}_{\mathrm{NO}_{3}}$ and $\delta^{18} \mathrm{O}_{\mathrm{NO}_{3}}$ in the bottom water below the euphotic zone on the continental shelf (i.e., [Sta. D5, 6'] in 2009 (Fig. 4b) and [Sta. D4'-11] in 2011 (Fig. 4c)) was evaluated considering the following two possibilities: (1) isotopic fractionation associated with $\mathrm{NO}_{3}$ assimilation by denitrifying bacteria, and (2) addition of $\mathrm{NO}_{3}$ from different sources. The effects of various $\mathrm{N}$ and $\mathrm{O}$ isotopes ranging from 5 to $25 \%$ with ${ }^{18} \varepsilon::^{15} \varepsilon$ ratios of 0.6 to 1.0 have been reported in culture experiments with denitrifying bacteria (Granger et al., 2008). In the field, active denitrification in the water column and an associated increase in $\delta^{15} \mathrm{~N}_{\mathrm{NO}_{3}}$ and $\delta^{18} \mathrm{O}_{\mathrm{NO}_{3}}$ have been reported in oxygendeficient layers with less than $4 \mu \mathrm{mol} \mathrm{L}^{-1}$ oxygen (Sigman et al., 2005). Moreover, positive $\mathrm{NO}_{3}$ flux from the water column to the sediment and subsequent denitrification have been widely reported on the continental shelf (Christensen et al., 1987), and several types of $\mathrm{NO}_{3}$ reduction (e.g., respiratory denitrification, anammox, and dissimilatory $\mathrm{NO}_{3}$ reduction to ammonium) have been estimated at the surface sediment of the ECS inner-shelf area near the Changjiang Estuary (Song et al., 2013). However, the minimum oxygen level of bottom water observed during our cruises was more than $100 \mu \mathrm{mol} \mathrm{L}-1$, which is too high to cause active denitrification in the water column. Furthermore, $\mathrm{N}^{*}$ (i.e., $\left.[\mathrm{DIN}]-16 \times\left[\mathrm{PO}_{4}^{3-}\right]+2.9\right)$ at the bottom layer on the continental shelf was positive (i.e., 0.6-6.4 in July 2009 and 2011; Tables 2 and 3), while $\mathrm{N}^{*}$ in the water mass intruding from the deep layer of the Okinawa Trough to the continental shelf was negative (i.e., -11.5 to -2.1 below $200 \mathrm{~m}$ depth in July 2009 and 2011; Tables 2 and 3), implying that the effect of denitrification at the sedimentary boundary layer on the $\mathrm{NO}_{3}$ characteristics of the ECS shelf water was insignificant during our observation period. On the other hand, locations at which water with slightly increased values $\left(\delta^{15} \mathrm{~N}_{\mathrm{NO}_{3}}=6.5-\right.$ $7.5 \%$ and $\delta^{18} \mathrm{O}_{\mathrm{NO}_{3}}=5.0-7.0 \%$ ) was sampled overlapping with the zone of YSCWM intrusion expected from the $T-S$ vertical profiles, and similar values were also observed in the bottom water of the northwestern area (i.e., lines A, B, and C; Figs. 5, 9) where YSCWM enters the ECS during summer. Therefore, the slightly increased values $\left(\delta^{15} \mathrm{~N}_{\mathrm{NO}_{3}}=6.5-\right.$ $7.5 \%$ and $\delta^{18} \mathrm{O}_{\mathrm{NO}_{3}}=5.0-7.0 \%$ ) are considered to be characteristic of the YSCWM.

Based on the above considerations, new $\mathrm{NO}_{3}$ at the northern ECS during summer seemed to originate from the Changjiang River discharge, KSSW, and YSCWM. At the relatively deeper chl $a$ maximum in the Okinawa Trough (i.e., depth of $65-75 \mathrm{~m}$ at Sta. D16), $\delta^{15} \mathrm{~N}_{\mathrm{NO}_{3}}$ data points from both 2009 and 2011 were located near the fractionation line that starts from the value of KSSW diluted with $\mathrm{NO}_{3}$ depleted water, suggesting that phytoplankton in the subsurface layer at the Okinawa Trough used $\mathrm{NO}_{3}$ originating from the KSSW (Fig. 8b and c). At the subsurface chl $a$ maximum from the mid-shelf to the outer shelf (i.e., depth of
15 to $30 \mathrm{~m}$ at Sta. $\left.\mathrm{D} 7^{\prime}-13\right), \delta^{15} \mathrm{~N}_{\mathrm{NO}_{3}}$ values for 2009 were located near the line beginning from the values of KSSWorigin $\mathrm{NO}_{3}$ and those for 2011 were located near the line beginning from YSCWM-derived $\mathrm{NO}_{3}$ (Fig. $8 \mathrm{~b}$ and c). The difference in the estimated $\mathrm{NO}_{3}$ sources for the phytoplankton growth on the ECS shelf between the years corresponds with hydrographic characteristics resulting in differences in KSSW and YSCWM development (see Sect. 4.1).

In the surface and subsurface water in the mid-shelf area (e.g., Sta. D7' in 2009, and Sta. D11 and 13 in 2011), where lower salinity was observed, $\delta^{15} \mathrm{~N}_{\mathrm{NO}_{3}}$ was plotted near the fractionation line starting from the typical $\mathrm{NO}_{3}$ value observed in the lower reach of the Changiiang River (Fig. 8b and c). This is a piece of strong evidence that CDW-carried $\mathrm{NO}_{3}$ was actually used by phytoplankton. On the other hand, the nitrate sampled at the inner mid-shelf area in 2011 (e.g., [Sta. D4'] (Fig. 8c) and [Sta. C1-3] (Fig. 9b)) were plotted around the center of fractionation lines originating from CDW-derived $\mathrm{NO}_{3}$ and $\mathrm{YSCWM}$-derived $\mathrm{NO}_{3}$ (Fig. 8c). Because there are variations in $\delta^{15} \mathrm{~N}_{\mathrm{NO}_{3}}-\ln \left[\mathrm{NO}_{3}\right]$ values in CDW observed near the Changjian River Estuary (cross symbols in Figs. 8 and 9; Chen et al. 2013), these values, which were observed in lower-salinity water, can be also explained as remaining $\mathrm{NO}_{3}$ after active uptake of ChangjianRiver-originated $\mathrm{NO}_{3}$ by phytoplankton. As another potential mechanism, surface CDW and subsurface YSCWM may have moderately mixed at shallower depths on the inner midshelf as suggested in $T-S$ diagrams (see Sect. 4.1; oval no. 2, Fig. 6c), and similar trends were also observed in the northern area (lines A and C; oval no. 2, Fig. 6c, and Fig. 9b). Therefore, the contribution of both CDW- and YSCWMderived $\mathrm{NO}_{3}$ is sufficient to explain the characteristics of $\mathrm{NO}_{3}$ sampled at the inner mid-shelf area in 2011. In July 2011, when Changjiang River discharge increased and the YSCWM was developed widely on the shelf, both YSCWM and CDW seemed to be major sources of $\mathrm{NO}_{3}$ and actually supported primary productivity on the continental shelf (Figs. 8c and 9b).

The uncertainty about isotopic fractionation associated with $\mathrm{NO}_{3}$ assimilation by phytoplankton species might have lead to misunderstanding of predominant $\mathrm{NO}_{3}$ sources. However, the $\mathrm{NO}_{3}$ sources for phytoplankton growth, which were evaluated by multiple isotopes of $\mathrm{NO}_{3}$, had good correspondence with the water dynamics determined by a physical approach based on $T-S$ diagrams. The analysis made by combining the $\delta^{15} \mathrm{~N}_{\mathrm{NO}_{3}}-\ln \left[\mathrm{NO}_{3}\right]$ diagram and the $T-S$ diagram clarified the reliable $\mathrm{NO}_{3}$ sources that were actually used by phytoplankton in the SMW of the northern ECS. Although TWCW and Kuroshio water, which contribute most to the water budget of the region, have been estimated to be major sources of $\mathrm{NO}_{3}$ based on nutrient budget models (Chen and Wang, 1999; Zhang et al., 2007a), our results show that CDW, YSCWM and KSSW are important nutrient sources for primary production at different locations on the northern continental shelf of the ECS. 


\subsection{Contributions of nitrification and atmospheric nitrogen to nitrate dynamics on the shelf}

In the previous section, we assumed that the $\delta^{15} \mathrm{~N}_{\mathrm{NO}_{3}}$ data points located between the fractionation lines $\left({ }^{15} \varepsilon=3\right)$ of Changjiang-River-carried $\mathrm{NO}_{3}$ and YSCWM-carried $\mathrm{NO}_{3}$ were attributed to Changjiang-River-carried $\mathrm{NO}_{3}$ having temporal variation of $\delta^{15} \mathrm{~N}_{\mathrm{NO}_{3}}-\ln \left[\mathrm{NO}_{3}\right]$ or mixing between the two water types. On the other hand, if ChangjiangRiver-discharged $\mathrm{NO}_{3}$ is continuously supplied to CDW, the $\delta^{15} \mathrm{~N}_{\mathrm{NO}_{3}}$ could also move to below the fractionation line based on the steady-state model (Fig. 10). However, in the open shelf, where the Changjiang River plume drifts in a northeasterly direction, it is not probable that river-derived $\mathrm{NO}_{3}$ was continuously supplied to the patch of the plume. The other most likely explanation is contribution of isotopically lighter $\mathrm{NO}_{3}$ from other sources.

Although deviation of $\delta^{15} \mathrm{~N}_{\mathrm{NO}_{3}}$ and $\delta^{18} \mathrm{O}_{\mathrm{NO}_{3}}$ from the $1: 1$ pattern and relatively lighter $\delta^{15} \mathrm{~N}_{\mathrm{NO}_{3}}$ expected from $\mathrm{NO}_{3}$ consumption (i.e., phytoplankton assimilation and denitrification) were potentially observed in the northern ECS (Figs. 4, 5, 8 and 9), a similar deviation pattern observed in other oceanic locations has been interpreted as evidence of nitrification in the presence of assimilation by phytoplankton (Wankel et al., 2007; Sugimoto et al., 2009) and/or $\mathrm{N}_{2}$ fixation in the zone of denitrification (Sigman et al., 2005).

When isotopic fractionation occurs during $\mathrm{NO}_{3}$ uptake following the Rayleigh model, the organic products (e.g., phytoplankton and denitrifying bacteria) will have isotopically lighter values than the residual $\mathrm{NO}_{3}$. After the organic products are consumed by heterotrophic organisms, isotopically lighter ammonium is excreted because of isotopic discrimination in the catabolic processes of $\mathrm{N}$ compounds through many chemical reactions, such as transamination (Balter et al., 2006). Furthermore, due to the large difference in isotopic fractionation $(\varepsilon)$ between ammonium assimilation and nitrification to $\mathrm{NO}_{3}$, the nitrogen directed back into the $\mathrm{NO}_{3}$ pool has lower $\delta^{15} \mathrm{~N}$ (indicated in Wankel et al., 2007). Therefore, the contribution of ammonium produced by decomposition and the subsequent ammoniumoxidized $\mathrm{NO}_{3}$ to the $\mathrm{NO}_{3}$ pool in the ECS may result in lower $\delta^{15} \mathrm{~N}_{\mathrm{NO}_{3}}$ vs. $\ln \left[\mathrm{NO}_{3}\right]$ compared to the values expected from residual $\mathrm{NO}_{3}$ during uptake by phytoplankton based on the Rayleigh model.

Many studies have reported the $f$ ratio (ratio of $\mathrm{NO}_{3}$ based new production to primary production) in ECS areas from the China coast to the shelf edge. Although the estimated $f$ ratios showed spatial and temporal variation (e.g., 0.25 to 0.74 in summer and 0.14 to 0.98 in winter; Chen et al., 2001), the values are generally less than 0.5 (Furuya et al., 1998; Chen et al., 1999, 2001; Chen and Chen, 2003), suggesting a high contribution of in situ remineralized nitrogen, directly as ammonium or as $\mathrm{NO}_{3}$ through nitrification, to primary production. Shiozaki et al. (2011) observed a considerable discrepancy between the $\mathrm{NO}_{3}$ assimi- lation rate $\left(1500 \mu \mathrm{mol} \mathrm{N} \mathrm{m} \mathrm{d}^{-2} \mathrm{~d}^{-1}\right)$ and the vertical $\mathrm{NO}_{3}$ flux $\left(98 \mu \mathrm{mol} \mathrm{N} \mathrm{m}{ }^{-2} \mathrm{~d}^{-1}\right)$ on the continental shelf of the ECS in July 2007, suggesting a contribution of nitrification within the euphotic zone. This is also supported by the existence of nitrifying Archaea (based on amoA gene), although the vertical flux of new $\mathrm{NO}_{3}$ was higher on or near the continental shelf in the ECS than in the open ocean (Shiozaki et al., 2011). Therefore, in the subsurface layers on the continental shelf in the northern ECS, for which the value $\left(\delta^{15} \mathrm{~N}_{\mathrm{NO}_{3}}\right.$ vs. $\left.\ln \left[\mathrm{NO}_{3}\right]\right)$ was plotted below the fractionation line of Changjiang-River-discharged $\mathrm{NO}_{3}$ (Figs. 8 and 9), the contribution of nitrification to $\mathrm{NO}_{3}$ dynamics at least in summer was also supported by stable isotope signatures in $\mathrm{NO}_{3}$.

In the Okinawa Trough, on the other hand, Liu et al. (1996) attributed relatively lower $\delta^{15} \mathrm{~N}_{\mathrm{NO}_{3}}$ at shallow depths than in the deeper layer to the contribution of $\mathrm{NO}_{3}$ derived from $\mathrm{N}_{2}$ fixation and estimated that $\mathrm{N}_{2}$ fixation supplies $500 \mu \mathrm{g} \mathrm{N} \mathrm{m}^{-2}$ day $^{-1}$, which accounts for $8 \%$ of the new nitrogen in the KSW. Shiozaki et al. (2010) also estimated that the mean bulk water $\mathrm{N}_{2}$ fixation by pico-, nano-, and microplanktonic diazotrophs was $232 \pm 54.8 \mu \mathrm{mol} \mathrm{N} \mathrm{m}^{-2} \mathrm{day}^{-1}$ in Kuroshio and ECS areas based on a ${ }^{15} \mathrm{~N}_{2}$-tracer method. Relatively higher $\mathrm{N}^{*}$ values in the water column on the continental shelf rather than that in deep water at the Okinawa Trough also corresponded with the contribution of $\mathrm{N}_{2}$ fixation (Tables 1-3), although $\mathrm{N}^{*}$ may be also enhanced due to river-derived nutrients having higher $\mathrm{N} / \mathrm{P}$ ratios (Wang et al., 2006). In addition, subtle increase of $\left[\mathrm{NO}_{3}\right]$ with relatively lower salinity of the surface water in the Philippine Sea next to the ECS was reported to be attributed to rainwaterderived $\mathrm{NO}_{3}$ (Kodama et al., 2011), and total amounts of DIN supplied through the atmospheric dry deposition to ECS was estimated to be comparable to the $\mathrm{N}$ supplied by biological $\mathrm{N}_{2}$ fixation (Yamada et al., 2013). The $\delta^{15} \mathrm{~N}_{\mathrm{NO}_{3}}$ in rainwater is also very low, around $0 \%$ (see Sect. 4.2 ), as is $\mathrm{N}_{2}$ fixation-derived nitrogen; however, $\delta^{15} \mathrm{~N}_{\mathrm{NO}_{3}}$ lower than that of the deep layer was not observed in shallow layers throughout the northern ECS, including the Okinawa Trough, during our survey periods. This is probably because there was no rainfall around the transects before and during our surveys, and $\mathrm{N}_{2}$ fixation occurs only occasionally in time and space in response to sporadic supply of the limiting nutrients (Fe and/or P) necessary for $\mathrm{N}_{2}$ fixation to occur (Shiozaki et al., 2010). Moreover, probable contribution of atmospheric nitrogen to $\mathrm{NO}_{3}$ dynamics in the oligotrophic surface and subsurface layer could be masked by a methodological limitation (i.e., $\delta^{15} \mathrm{~N}_{\mathrm{NO}_{3}}$ was not measured for water samples with $\left[\mathrm{NO}_{3}\right]$ less than $\left.1.5 \mu \mathrm{M}\right)$. On the other hand, in case nitrification and/or atmospheric nitrogen contribute to $\mathrm{NO}_{3}$ dynamics at surface and subsurface layers, the contribution of new $\mathrm{NO}_{3}$ having heavier $\delta^{15} \mathrm{~N}$ values (e.g., ChangjiangRiver-discharged $\mathrm{NO}_{3}$ ) may have been offset and underestimated. Therefore, the contribution of $\mathrm{CDW}$-derived $\mathrm{NO}_{3}$ may be re-evaluated to be higher, especially at the location where salinity was relatively low (e.g., Sta. A1, B1 in July 2009; 
Table 2 and Fig. 9a), although the use of CDW-derived $\mathrm{NO}_{3}$ in surface and subsurface water seemed to be limited in July 2009 based on $\delta^{15} \mathrm{~N}_{\mathrm{NO}_{3}}-\ln \left[\mathrm{NO}_{3}\right]$ diagram (see Sect. 4.2).

Because there is considerable uncertainty about the specific isotopic fractionation occurring during $\mathrm{NO}_{3}$ assimilation in plankton species, the extent of the contributions of nitrification and nitrogen fixation, their spatial and temporal variation, and the absolute rates and contributions of each biological process (i.e., assimilation, remineralization, nitrification, and nitrogen fixation) were not accurately quantified in this study. However, the $\mathrm{NO}_{3}$ dynamics (i.e., supply, dilution, and reduction due to biological use) in the bottom water and deep areas below the euphotic zone seemed to be controlled mainly by physical factors, such as intrusion of and mixing of water masses, which have specific characteristics of $\mathrm{NO}_{3}$ concentration and stable isotopic values, although there could be contributions from many biological reactions, including nitrification associated with ammonium diffusion from the sediment (Zhang et al., 2007a; Granger et al., 2011). In addition to physical factors, on the other hand, assimilation of $\mathrm{NO}_{3}$ by phytoplankton was probably the major driver of $\mathrm{NO}_{3}$ dynamics in the surface and subsurface euphotic zone causing changes in $\delta^{15} \mathrm{~N}_{\mathrm{NO}_{3}}$ and $\delta^{18} \mathrm{O}_{\mathrm{NO}_{3}}$, especially during summer. Further research on the spatial and temporal variation in stable isotopes of $\mathrm{NO}_{3}$, including the lower concentration throughout the ECS continental shelf combined with other parameters, will be useful for understanding the nutrient dynamics affecting actual phytoplankton growth.

\section{Conclusions}

Based on a survey of dual isotopes of $\mathrm{NO}_{3}, \delta^{15} \mathrm{~N}_{\mathrm{NO}_{3}}-$ $\ln \left[\mathrm{NO}_{3}\right]$ dynamics, and $T-S$ diagrams, different sources of $\mathrm{NO}_{3}$ and their actual use by phytoplankton were successfully identified in the northern ECS. Typical $\delta^{15} \mathrm{~N}_{\mathrm{NO}_{3}}$ and $\delta^{18} \mathrm{O}_{\mathrm{NO}_{3}}$ were distinctly different among the potential $\mathrm{NO}_{3}$ sources (i.e., 5.5-6.0 and 3.5-4.0\%o for KSSW, 6.5-7.5\%o and $5.0-7.0 \%$ for YSCWM, 8.3 and $2.6 \%$ or Changjiang river, $0.4 \pm 2.9$ and $73.3 \pm 9.8 \%$ or rainwater, respectively) and therefore potentially useful for tracing the source of $\mathrm{NO}_{3}$, which is the main DIN component in the ECS. In winter, KSSW and YSMW contributed predominantly to $\mathrm{NO}_{3}$ distributed in the shelf water, and mixing between the $\mathrm{NO}_{3}$ rich $\mathrm{KSSW}$ and $\mathrm{NO}_{3}$-depleted but warm $\mathrm{KSW}$ seemed to stimulate phytoplankton production in the surface water of the Okinawa Trough, but YSMW-carried $\mathrm{NO}_{3}$ on the shelf was not actively used by phytoplankton probably due to limitations of temperature and light. In summer, except at times when episodic events such as typhoons mixed the water from the surface to the bottom (Siswanto et al., 2008b; Hung and Gong 2011), $\mathrm{NO}_{3}$ from CDW, YSCWM and KSSW (the contributions of which were controlled by Changjiang discharge and the spreading of the YSCWM in the bottom shelf water) affected the distribution and abundance of $\mathrm{NO}_{3}$ in the north- ern ECS. Isotopic fractionation during $\mathrm{NO}_{3}$ uptake by phytoplankton had drastically increased $\delta^{15} \mathrm{~N}_{\mathrm{NO}_{3}}$ and $\delta^{18} \mathrm{O}_{\mathrm{NO}_{3}}$ in summer, and provided evidence on the utilization of $\mathrm{NO}_{3}$ originated from each source that stimulated phytoplankton growth at different locations. Relatively lighter $\delta^{15} \mathrm{~N}_{\mathrm{NO}_{3}}$ than expected from the fractionation effect during algal uptake might be explained by contribution of atmospheric fixed nitrogen and/or nitrification to $\mathrm{NO}_{3}$ dynamics in the surface and subsurface layers. If nitrification was the major contribution to the isotopically light $\mathrm{NO}_{3}$, this would imply a tightly coupled nitrogen cycle in the shelf water of the northern ECS.

Acknowledgements. We thank T. Matsuno (Kyusyu Univ.), J. Zhang (Toyama Univ.), and S. Takeda (Nagasaki Univ.) for many discussions to interpret the data. The crew of RV Yoko-Maru and TV Nagasaki-Maru kindly helped water sampling and CTD measurement. Stable isotopes analyses were conducted using Cooperative Research Facilities (Isotope Ratio Mass Spectrometer) of Center for Ecological Research, Kyoto University. This study was financially supported by Japan Society for the Promotion of Science (JSPS) Research Fellowships for Young Scientists and the Study of Kuroshio Ecosystem Dynamics for Sustainable Fisheries (SKED) funded by the MEXT (Ministry of Education, Culture, Sports, Science and Technology), Japan. We are grateful to guest editor, K.-K. Liu, and anonymous reviewers for providing valuable and constructive comments to improve the manuscript.

Edited by: K.-K. Liu

\section{References}

Altabet, M. A., Deuser, W. G., Honjyo, S., and Stienen, C.: Seasonal and depth-related changes in the source of sinking particles in the North Atlantic, Nature, 354, 136-138, 1991.

Balter, V., Simon, L., Fouillet, H., and Lecuyer, C.: Box-modeling of ${ }^{15} \mathrm{~N} /{ }^{14} \mathrm{~N}$ in mammals, Oecologia, 147, 212-222, 2006.

Casciotti, K. L., Sigman, D. M., Hastings, M. G., Bohlke, J. K., and Hilkert, A.: Measurement of the oxygen isotopic composition of nitrate in seawater and freshwater using the denitrifier method, Anal. Chem., 74, 4905-4912, 2002.

Chai, C., Yu, Z., Shen, Z., Song, X., Cao, X., and Yao, Y.: Nutrient characteristics in the Yangtze River Estuary and the adjacent East China Sea before and after impoundment of the Three Gorges Dam, Sci. Total Environ., 407, 4687-4695, 2009.

Chen, C. T. A.: Distributions of nutrients in the East China Sea and the South China Sea connection, J. Oceanogr., 64, 737-751, 2008.

Chen, C. T. A. and Wang, S. L.: Carbon, alkalinity and nutrient budgets on the East China Sea continental shelf, J. Geophys. Res., 104, 20675-20686, 1999.

Chen, D. J. Z. and MacQuarrie, K. T. B.: Correlation of $\delta^{15} \mathrm{~N}$ and $\delta^{18} \mathrm{O}$ in $\mathrm{NO}_{3}^{-}$during denitrification in groundwater, J. Environ. Eng. Sci., 4, 221-226, 2005.

Chen, F. J., Chen, J. F., Jia, G. D., Jin, H. Y., Xu, J., Yang, Z., Zhuang, Y. P., Liu, X. Z., and Zhang, H. S.: Nitrate $\delta^{15} \mathrm{~N}$ and $\delta^{18} \mathrm{O}$ evidence for active biological transformation in the Changjiang Estuary and the adjacent East China Sea, 
Acta Oceanol. Sin., 32, 11-17, doi:10.1007/s13131-013-0294-4, 2013.

Chen, Y. L. L. and Chen, H. Y.: Nitrate-based new production and its relationship to primary production and chemical hydrography in spring and fall in the East China Sea, Deep-Sea Res. Pt. II, 50, 1249-1264, 2003.

Chen, Y. L. L., Lu, H. B., Shiah, F. K., Gong, G. C., Liu, K. K., and Kanda, J.: New production and f-ratio on the continental shelf of the East China Sea: Comparisons between nitrate inputs from the subsurface Kuroshio current and the Changjiang River, Estuar. Coast. Shelf S., 48, 59-75, 1999.

Chen, Y. L. L., Chen, H. Y., Lee, W. H., Hung, C. C., Wong, G. T. F., and Kanda, J.: New production in the East China Sea, comparison between well-mixed winter and stratified summer conditions, Cont. Shelf Res., 21, 751-764, 2001.

Chiang, K. P., Chou, Y. H., Chang, J., and Gong, G. C.: Winter Distribution of Diatom Assemblages in the East China Sea, J. Oceanogr., 60, 1053-1062, 2004.

Dai, X., Lu, D., Guan, W., Xia, P., Wang, H., He, P., and Zhang, D.: The Correlation between Prorocentrum donghaiense Blooms and the Taiwan Warm Current in the East China Sea - Evidence for the "Pelagic Seed Bank" Hypothesis, PLoS ONE, 8, e64188, doi:10.1371/journal.pone.0064188, 2013

Furuya, K., Hama, T., Kanda, J., and Odate, T.: Primary production in the East China Sea, B. Coast. Oceanogr., 36, 19-28, 1998.

Furuya, K., Hayashi, M., Yabushita, Y., and Ishikawa, A.: Phytoplankton dynamics in the East China Sea in spring and summer as revealed by HPLC-derived pigment signatures, Deep-Sea Res. Pt. II, 50, 367-387, 2003.

Gong, G. C., Chen, Y. L. L., and Liu, K. K.: Chemical hydrography and chlorophyll a distribution in the East China Sea in summer: implications in nutrient dynamics, Cont. Shelf Res., 16, 15611590, 1996.

Gong, G. C., Chang, J., Chiang, K. P., Hsiung, T. M., Hung, C. C., Duan, S. W., and Codispoti, L. A.: Reduction of primary production and changing of nutrient ratio in the East China Sea: Effect of the Three Gorges Dam?, Geophys. Res. Lett., 33, L07610, doi:10.1029/2006GL025800, 2006.

Granger, J., Sigman, D. M., Needoba, J. A., and Harrison, P. J.: Coupled nitrogen and oxygen isotope fractionation of nitrate during assimilation by cultures of marine phytoplankton, Limnol. Oceanogr., 49, 1763-1773, 2004.

Granger, J., Sigman, D. M., Lehmann, M. F., and Tortell, P. D.: Nitrogen and oxygen isotope fractionation during dissimilatory nitrate reduction by denitrifying bacteria, Limnol. Oceanogr., 53, 2533-2545, 2008.

Granger, J., Sigman, D. M., Rohde, M. M., Maldonado, M. T., and Tortell, P. D.: $\mathrm{N}$ and $\mathrm{O}$ isotope effects during nitrate assimilation by unicellular prokaryotic and eukaryotic plankton cultures, Geochim. Cosmochim. Ac., 74, 1030-1040, 2010.

Granger, J., Prokopenko, M. G., Sigman, D. M., Mordy, C. W., Morse, Z. M., Morales, L. V., Sambrotto, R. N., and Plessen, B.: Coupled nitrification-denitrification in sediment of the eastern Bering Sea shelf leads to ${ }^{15} \mathrm{~N}$ enrichment of fixed $\mathrm{N}$ in shelf waters, J. Geophys. Res., 116, C11006, doi:10.1029/2010JC006751, 2011.

Guo, X., Miyazawa, Y., and Yamagata, T.: The Kuroshio onshore intrusion along the shelf break of the East China Sea: The origin of the Tsushima Warm Current, J. Phys. Oceanogr., 36, 22052231, 2006.

Han, A. Q., Dai, M. H., Gan, J. P., Kao, S.-J., Zhao, X. Z., Jan, S., Li, Q., Lin, H., Chen, C.-T. A., Wang, L., Hu, J. Y., Wang, L. F., and Gong, F.: Inter-shelf nutrient transport from the East China Sea as a major nutrient source supporting winter primary production on the northeast South China Sea shelf, Biogeosciences, 10, 81598170, doi:10.5194/bg-10-8159-2013, 2013.

Hiyama, Y., Yoda, M., and Ohshimo, S.: Stock size fluctuations in chub mackerel (Scomber japonicus) in the East China Sea and the Japan/East Sea, Fish. Oceanogr., 11, 347-353, 2002.

Hung, C. C. and Gong G. G.: Biogeochemical responses in the southern East China Sea after typhoons, Oceanography, 24, 4251,2011

Isobe, A. and Matsuno, T., Long-distance nutrient-transport process in the Changjiang river plume on the East China Sea shelf in summer, J. Geophys. Res., 113, C04006, doi:10.1029/2007JC004248, 2008.

Isobe, A., Fujiwara, Y., Chang, P. H., Sugimatsu, K., Shimizu, M., Matsuno, T., and Manda, A.: Intrusion of Less Saline Shelf Water into the Kuroshio Subsurface Layer in the East China Sea, J. Oceanogr., 60, 853-863, 2004.

Jacobs, G. A., Hur, H. B., and Riedlinger, S. K.: Yellow and East China Seas response to winds and currents, J. Geophys. Res., 105, 21947-21968, 2000.

Kiyomoto, Y., Hasegawa, T., Gomi, Y., Sasaki, H., Nishiuchi, K., Okamura, K., Koshikawa, H., Higashi, H., Akiyama, H., and Nakata, H.: Long-term changes in nutrients in the Changjiang Diluted Water on the East China Sea - Relationships between the phytoplankton species and nutrients from the Changjiang River, Umi to Sora, 88, 109-120, 2013 (Japanese with English abstract)

Kodama, T., Furuya, K., Hashihama, F., Takeda, S., and Kanda, J.: Occurrence of rain-origin nitrate patches at the nutrientdepleted surface in the East China Sea and the Philippine Sea during summer, J. Geophys. Res., 116, C08003, doi:10.1029/2010JC006814, 2011

Lee, J. S. and Matsuno, T.: Intrusion of Kuroshio water onto the continental shelf of the East China Sea, J. Oceanogr., 63, 309325, 2007.

Leichter, J. J., Paytan, A., Wankel, S., Hanson, K., Miller, S., and Altabet, M. A.: Nitrogen and oxygen isotopic signatures of subsurface nitrate seaward of the Florida Keys reef tract, Limnol. Oceanogr., 52, 1258-1267, 2007.

Li, D. and Daler, D.: Ocean Pollution from Land-based Sources: East China Sea, China, AMBIO, 33, 107-113, 2004.

Li, J., Wei, H., Zhang, Z., and Lu, Y.: A modeling study of interannual variation of Kuroshio intrusion on the shelf of East China Sea, J. Ocean Univ. China, 12, 537-548, 2013.

Li, S. L., Liu, C. Q., Li, J., Liu, X., Chetelat, B., Wang, B., and Wang, F.: Assessment of the Sources of Nitrate in the Changjiang River, China Using a Nitrogen and Oxygen Isotopic Approach, Environ. Sci. Technol., 44, 1573-1578, 2010.

Liu, K. K., Su, M. J., Hsueh, C. R., and Gong, G. C.: The nitrogen isotopic composition of nitrate in the Kuroshio Water northeast of Taiwan: evidence for nitrogen fixation as a source of isotopically light nitrate, Mar. Chem., 54, 273-292, 1996.

Liu, K. K., Chao, S. Y., Lee, H. J., Gong, G. C., and Teng, Y. C.: Seasonal variation of primary productivity in the East China Sea: 
a numerical study based on coupled physical-biogeochemical model, Deep-Sea Res. Pt. II, 57, 1762-1782, 2010a.

Liu, K. K., Gong, G. C., Wu, C. R., and Lee, H. J.: 3.2. The Kuroshio and the East China Sea, in: Carbon and Nutrient Fluxes in Continental Margins: A Global Synthesis, edited by: Liu, K.K., Atkinson, L., Quiñones, R., and Talaue-McManus, L., IGBP Book Series, Springer, Berlin, 124-146, $2010 \mathrm{~b}$.

Matsuno, T., Kanari, S., Kobayashi, C., and Hibiya, T.: Vertical mixing in the bottom mixed layer near the continental shelf break in the East China Sea, J. Oceanogr. 50, 437-448, 1994.

Matsuno, T., Lee, J.-S., Shimizu, M., Kim, S.-H., and Pang I.-C.: Measurements of the turbulent energy dissipation rate and an evaluation of the dispersion process of the Changjiang Diluted Water in the East China Sea, J. Geophys. Res., 111, C11S09, doi:10.1029/2005JC003196, 2006.

Moon, J. H., Hirose, N., and Yoon, J. H.: Comparison of wind and tidal contributions to seasonal circulation of the Yellow Sea, J. Geophys. Res., 114, C08016, doi:10.1029/2009JC005314, 2009.

Nakamura, T., Matsumoto, K., and Uematsu, M.: Chemical characteristics of aerosols transported from Asia to the East China Sea, an evaluation of anthropogenic combined nitrogen deposition in autumn, Atmos. Environ., 39, 1749-1758, 2005.

Nakamura, T., Ogawa, H., Maripi, D. K., and Uematsu, M.: Contribution of water soluble organic nitrogen to total nitrogen in marine aerosols over the East China Sea and western North Pacific, Atmos. Environ., 40, 7259-7264, 2006.

Needoba, J., Waser, N. A., Harrison, P. J., and Calvert, S. E.: Nitrogen isotope fractionation in 12 species of marine phytoplankton during growth on nitrate, Mar. Ecol.-Prog. Ser., 255, 81-91, 2003.

Sakurai, Y., Kiyofuji, H., Saitoh, S., Goto, T., and Hiyama, Y.: Changes in inferred spawning areas of Todarodes pacificus (Cephalopoda: Ommastrephidae) due to changing environmental conditions, ICES J. Mar. Sci., 57, 24-30, 2000.

Sassa, C., Yamamoto, K., Tsukamoto, Y., Konishi, Y., and Tokimura, M.: Distribution and migration of age-0 jack mackerel (Trachurus japonicus) in the East China and Yellow Seas, based on seasonal bottom trawl surveys, Fish. Oceanogr., 18, 255-267, 2009.

Shiozaki, T., Furuya, K., Kodama, T., Kitajima, S., Takeda, S., Takemura, T., and Kanda, J.: New estimation of N fixation in the western and central Pacific Ocean and its marginal seas, Global Biogeochem. Cy., 24, GB1015, doi:10.1029/2009GB003620, 2010.

Shiozaki, T., Furuya, K., Kurotori, H., Kodama, T., Takeda, S., Endoh, T., Yoshikawa, Y., Ishizaka, J., and Matsuno, T.: Imbalance between vertical nitrate flux and nitrate assimilation on a continental shelf: Implications of nitrification, J. Geophys. Res., 116, C10031, doi:10.1029/2010JC006934, 2011.

Sigman, D. M., Altabet, M. A., McCorkle, D. C., Francois, R., and Fischer, G.: The $\delta^{15} \mathrm{~N}$ of nitrate in the southern ocean: Consumption of nitrate in surface waters, Global Biogeochem. Cy., 13, 1149-1166, 1999.

Sigman, D. M., Casciotti, K. L., Andreani M., Barford, C., Galanter, M., and Bohlke, J. K.: A bacterial method for the nitrogen isotopic analysis of nitrate in seawater and freshwater, Anal. Chem., 73, 4145-4153, 2001.

Sigman, D. M., Granger, J., DiFiore, P. J., Lehmann, M. M., Ho, R., Cane, G. and van Geen, A.; Coupled nitrogen and oxygen isotope measurements of nitrate along the eastern
North Pacific margin, Global Biogeochem. Cy., 19, GB4022, doi:10.1029/2005GB002458, 2005.

Siswanto, E., Nakata, H., Matsuoka, Y., Tanaka, K., Kiyomoto, Y., Okamura, K., Zhu, J., and Ishizaka, J.: The long-term freshening and nutrient increases in summer surface water in the northern East China Sea in relation to Changjiang discharge variation, J. Geophys. Res., 113, C10030, doi:10.1029/2008JC004812, 2008a.

Siswanto, E., Ishizaka, J., Morimoto, A., Tanaka, K., Okamura, K., Kristijono, A., and Saino, T.: Ocean physical and biogeochemical responses to the passage of Typhoon Meari in the East China Sea observed from Argo float and multiplatform satellites, Geophys. Res. Lett., 35, L15604, doi:10.1029/2008GL035040, 2008 b.

Song, G. D., Liu, S. M., Marchant, H., Kuypers, M. M. M., and Lavik, G.: Anammox, denitrification and dissimilatory nitrate reduction to ammonium in the East China Sea sediment, Biogeosciences, 10, 6851-6864, doi:10.5194/bg-10-6851-2013, 2013.

Sugimoto, R., Kasai, A., Miyajima, T., and Fujita, K.: Transport of oceanic nitrate from the continental shelf to the coastal basin in relation to the path of the Kuroshio, Cont. Shelf Res., 29, 16781688, 2009.

Teranes, J. L. and Bernasconi, S. M.: The record of nitrate utilization and productivity limitation provided by $\delta^{15} \mathrm{~N}$ values in lake organic matter? A study of sediment trap and core sediments from Baldeggersee, Switzerland, Limnol. Oceanogr., 45, 801$813,2000$.

Uye, S.: Blooms of the giant jellyfish Nemopilema nomurai: a threat to the fisheries sustainability of the East Asian Marginal Seas, Plankton Benthos Res., 3, 125-131, 2008.

Wang, B.: Cultural eutrophication in the Changjiang (Yangtze River) plume: History and perspective, Estuar. Coast. Shelf S., 69, 471-477, 2006.

Wankel, S., Kendall, C., Pennington, J. T., Chavez, F. P., and Paytan, A.: Nitrification in the euphotic zone as evidenced by nitrate dual isotopic composition: Observations from Monterey Bay, California, Global Biogeochem. Cy., 21, GB2009, doi:10.1029/2006GB002723, 2007.

Waser, N. A., Yu, Z., Yin, K., Nielsen, B., Harrison, P. J., Turpin, D. H., and Calvert, S. E.: Nitrogen isotopic fractionation during a simulated diatom spring bloom: importance of $\mathrm{N}$-starvation in controlling fractionation, Mar. Ecol.-Prog. Ser., 179, 291-296, 1999.

Wong, G. T. F., Gong, G. C., Liu, K. K., and Pai, S. C.: 'Excess Nitrate' in the East China Sea, Estuar. Coast. Shelf S., 46, 411418, 1998.

Yamada, M., Takeda, S., Tamura, K., Shiota, Y., and Yoshimura, H.: Nutrient supply fluxes from atmosphere to ocean at the eastern East China Sea. Bulletin of the Faculty of Fisheries Nagasaki University, 94, 1-7, 2013. (Japanese with English abstract).

Yamaguchi, H., Kim, H. C., Son, Y. B., Kim, S. W., Okamura, K., Kiyomoto, Y., and Ishizaka, J.: Seasonal and summer inter annual variations of SeaWiFS chlorophyll a in the Yellow Sea and East China Sea, Progr. Oceanogr., 105, 22-29, 2012.

Yanagi, T., Shimizu, T., and Lie, H. J.: Detailed structure of the Kuroshio frontal eddy along the shelf edge of the East China Sea, Cont. Shelf Res., 18, 1039-1056, 1998

Zhang, J., Liu, S. M., Ren, J. L., Wu, Y., and Zhang, G. L.: Nutrient gradients from the eutrophic Changjiang (Yangtze River) Estuary to the oligotrophic Kuroshio waters and re-evaluation of 
budgets for the East China Sea Shelf, Progr. Oceanogr., 74, 449478, 2007a.

Zhang, L., Liu, Z., Zhang, J., Hong, G. H., Park, Y., and Zhang, H. F.: Reevaluation of mixing among multiple water masses in the shelf: An example from the East China Sea, Cont. Shelf Res., 27, 1969-1979, 2007b.
Zhang, S. W., Wang, Q. Y., Lu, Y., Cui, H., and Yuan, Y. L.: Observation of the seasonal evolution of the Yellow Sea Cold Water Mass in 1996-1998, Cont. Shelf Res., 28, 442-457, 2008.

Zhu, J., Chen, C., Ding, P., Li, C., and Lin, H.: Does the Taiwan warm current exist in winter?, Geophys. Res. Lett., 31, L12302, doi:10.1029/2004GL019997, 2004. 